\title{
Interpreting the ultraviolet aerosol index observed with the OMI satellite instrument to understand absorption by organic aerosols: implications for atmospheric oxidation and direct radiative effects
}

\author{
Melanie S. Hammer ${ }^{1}$, Randall V. Martin ${ }^{1,2}$, Aaron van Donkelaar ${ }^{1}$, Virginie Buchard ${ }^{3,4}$, Omar Torres ${ }^{3}$, \\ David A. Ridley ${ }^{5}$, and Robert J. D. Spurr ${ }^{6}$ \\ ${ }^{1}$ Department of Physics and Atmospheric Science, Dalhousie University, Halifax, Canada \\ ${ }^{2}$ Harvard-Smithsonian Center for Astrophysics, Cambridge, MA, USA \\ ${ }^{3}$ NASA/Goddard Space Flight Center, Greenbelt, MD, USA \\ ${ }^{4}$ GESTAR/Universities Space Research Association, Columbia, MD, USA \\ ${ }^{5}$ Department of Civil and Environmental Engineering, Massachusetts Institute of Technology, Cambridge, MA, USA \\ ${ }^{6}$ RT Solutions, Inc., 9 Channing Street, Cambridge, MA, USA
}

Correspondence to: Melanie S. Hammer (melanie.hammer@dal.ca)

Received: 14 September 2015 - Published in Atmos. Chem. Phys. Discuss.: 12 October 2015

Revised: 25 January 2016 - Accepted: 16 February 2016 - Published: 1 March 2016

\begin{abstract}
Satellite observations of the ultraviolet aerosol index (UVAI) are sensitive to absorption of solar radiation by aerosols; this absorption affects photolysis frequencies and radiative forcing. We develop a global simulation of the UVAI using the 3-D chemical transport model GEOSChem coupled with the Vector Linearized Discrete Ordinate Radiative Transfer model (VLIDORT). The simulation is applied to interpret UVAI observations from the Ozone Monitoring Instrument (OMI) for the year 2007. Simulated and observed values are highly consistent in regions where mineral dust dominates the UVAI, but a large negative bias $(-0.32$ to -0.97$)$ exists between simulated and observed values in biomass burning regions. We determine effective optical properties for absorbing organic aerosol, known as brown carbon $(\mathrm{BrC})$, and implement them into GEOS-Chem to better represent observed UVAI values over biomass burning regions. The inclusion of absorbing $\mathrm{BrC}$ decreases the mean bias between simulated and OMI UVAI values from -0.57 to -0.09 over West Africa in January, from -0.32 to +0.0002 over South Asia in April, from -0.97 to -0.22 over southern Africa in July, and from -0.50 to +0.33 over South America in September. The spectral dependence of absorption after including $\mathrm{BrC}$ in the model is broadly consistent with reported observations for biomass burning aerosol, with absorbing Ångström exponent (AAE) values ranging from 2.9 in the
\end{abstract}

ultraviolet (UV) to 1.3 across the UV-Near IR spectrum. We assess the effect of the additional UV absorption by $\mathrm{BrC}$ on atmospheric photochemistry by examining tropospheric hydroxyl radical $(\mathrm{OH})$ concentrations in GEOS-Chem. The inclusion of $\mathrm{BrC}$ decreases $\mathrm{OH}$ by up to $30 \%$ over South America in September, up to $20 \%$ over southern Africa in July, and up to $15 \%$ over other biomass burning regions. Global annual mean $\mathrm{OH}$ concentrations in GEOS-Chem decrease due to the presence of absorbing $\mathrm{BrC}$, increasing the methyl chloroform lifetime from 5.62 to 5.68 years, thus reducing the bias against observed values. We calculate the direct radiative effect (DRE) of $\mathrm{BrC}$ using GEOS-Chem coupled with the radiative transfer model RRTMG (GC-RT). Treating organic aerosol as containing more strongly absorbing BrC changes the global annual mean all-sky top of atmosphere (TOA) DRE by $+0.03 \mathrm{~W} \mathrm{~m}^{-2}$ and all-sky surface DRE by $-0.08 \mathrm{~W} \mathrm{~m}^{-2}$. Regional changes of up to $+0.3 \mathrm{~W} \mathrm{~m}^{-2}$ at TOA and down to $-1.5 \mathrm{~W} \mathrm{~m}^{-2}$ at the surface are found over major biomass burning regions. 


\section{Introduction}

Absorption of solar radiation by aerosols plays a major role in radiative forcing and atmospheric photochemistry. Aerosol absorption has been estimated to be the second largest source of radiative forcing after carbon dioxide (Bond et al., 2013; IPCC, 2014; Ramanathan and Carmichael, 2008), although considerable uncertainty remains regarding the magnitude of the forcing (Stier et al., 2007; Wang et al., 2014). Absorption of ultraviolet (UV) radiation by aerosols decreases photolysis frequencies, leading to a reduction in the concentrations of atmospheric oxidants (Dickerson et al., 1997; Jacobson, 1998; Liao et al., 2003; Martin et al., 2003). Many atmospheric chemistry models tend to overestimate tropospheric hydroxyl radical $(\mathrm{OH})$ concentrations compared to observations (Mao et al., 2013; Naik et al., 2013). Accurately representing aerosol absorption could help rectify the discrepancies between simulated and observed $\mathrm{OH}$ concentrations, and offer constraints on radiative forcing.

The ultraviolet aerosol index (UVAI) is a method of detecting aerosol absorption using satellite measurements. The UVAI is calculated by separating the spectral contrast of radiances due to aerosol effects from those due to Rayleigh scattering at two wavelengths in the near-UV region (Herman et al., 1997; Torres et al., 1998, 2007). Two attributes of the UVAI method are (1) that aerosol optical properties are more readily detected over surfaces with low reflectance such as found in the UV (Torres et al., 2005), and (2) that the strong interaction between aerosol absorption and molecular scattering in the near-UV increases the sensitivity of UVradiances to aerosol absorption (Torres et al., 1998). These attributes enhance the ability of the UVAI to detect aerosol absorption that affects UV photolysis and radiative forcing.

Traditionally, black carbon (BC) is treated as the predominant absorbing carbonaceous aerosol, and all organic carbon is assumed to be primarily scattering or weakly absorbing colorless aerosol. However, a growing number of observations have found evidence of significant absorption by a subset of organic carbon, known as "brown carbon" $(\mathrm{BrC})$, which is strongest in the ultraviolet and decreases into the visible and near-IR wavelength regions (Bergstrom et al., 2007; Chen and Bond, 2010; Kirchstetter et al., 2004; Martins et al., 2009; Yang et al., 2008; Zhong and Jang, 2014). The majority of $\mathrm{BrC}$ is emitted to the atmosphere through low-temperature, incomplete combustion of biomass and biofuel (Chen and Bond, 2010; Kirchstetter et al., 2004; Zhong and Jang, 2014). There is evidence of a possible source from residential coal burning (Bond, 2001), while the high-temperature environment associated with other fossil fuel combustion is unfavorable to $\mathrm{BrC}$ formation (Andreae and Gelencsér, 2006; Saleh et al., 2014). BrC has been observed to contribute significantly to the overall absorption by biomass burning aerosol, especially in the UV (Clarke et al., 2007; Corr et al., 2012; Kirchstetter and Thatcher, 2012).
The UVAI is sensitive to this absorption (Jethva and Torres, 2011).

A great deal of uncertainty exists regarding the fraction of total primary organic carbon that is brown $(\mathrm{BrC} / \mathrm{POC})$. This uncertainty arises from the variety of methods used to measure $\mathrm{BrC}$ absorption as well as the variable nature of organic aerosols themselves (Lack and Langridge, 2013). Filter-based measurements where the organic carbon is extracted from the total biomass burning aerosol sample with the use of solvents range from 50 to $90 \%$ (Chen and Bond, 2010; Kirchstetter et al., 2004). A broad range of BrC/POC values have been used to simulate absorption by brown carbon. For example, Feng et al. (2013) assume that $66 \%$ of primary organic carbon from biomass and biofuel emissions is brown, Wang et al. (2014) assume that $50 \%$ of POC from biomass and $25 \%$ of POC from biofuel emissions is brown, while Lin et al. (2014) assume that $100 \%$ POC from biomass and biofuel emissions is brown. Global observations of reflected solar radiation used in the UVAI could offer a constraint on these different assumptions.

Several estimates of $\mathrm{BrC}$ absorption exist, but they all differ significantly. The imaginary part of the refractive index (k) for BrC derived by Kirchstetter et al. (2004) and Chen and Bond (2010) are often taken, respectively, as the upper $(k \sim 0.168$ at $350 \mathrm{~nm})$ and lower $(k \sim 0.074$ at $350 \mathrm{~nm})$ limits in modeling studies (Arola et al., 2011; Feng et al., 2013; Lin et al., 2014). Different observations may reflect different burn conditions (Saleh et al., 2014) as well as chemical loss and evaporation of $\mathrm{BrC}$ (Forrister et al., 2015; Zhong and Jang, 2014). Global observations are needed to infer the effective absorption across a variety of conditions. Many studies have estimated the direct radiative effect (DRE) and/or direct radiative forcing (DRF) by BrC. In Heald et al. (2014) a clear distinction is made between the DRE, which is the instantaneous imbalance of out-going longwave and incoming shortwave radiation due to the presence of an atmospheric constituent, and the DRF, which is the difference in DRE between present-day and preindustrial conditions. Prior estimates of the change in all-sky top of atmosphere (TOA) DRE from treating organic aerosol as containing $\mathrm{BrC}$ range from $+0.04 \mathrm{~W} \mathrm{~m}^{-2}$ to $+0.25 \mathrm{~W} \mathrm{~m}^{-2}$ globally (Chung et al., 2012; Feng et al., 2013), with estimates of regional seasonal DRE of organic aerosol including absorbing $\mathrm{BrC}$ ranging from +0.5 to $1 \mathrm{~W} \mathrm{~m}^{-2}$ (Arola et al., 2015). Most studies estimate a TOA DRF of between 0.07 and $0.57 \mathrm{~W} \mathrm{~m}^{-2}$ due to absorption by BrC (Lin et al., 2014; Park et al., 2010; Wang et al., 2014). Following submission of our paper, we learned of a submitted paper by Jo et al. (2015) that developed a global simulation of $\mathrm{BrC}$ and applied it to investigate atmospheric photochemistry. To our knowledge, this work and that by Jo et al. (2015) are the first two chemical transport modeling studies that have considered the effect of absorption by $\mathrm{BrC}$ on atmospheric photochemistry.

In this work we introduce $\mathrm{BrC}$ to the chemical transport model GEOS-Chem and examine its effect on at- 
mospheric absorption and photochemistry, in particular in known biomass burning regions. To evaluate aerosol absorption, Sect. 3 develops a simulation of the UVAI following Buchard et al. (2015) using the Vector Linearized Discrete Radiative Transfer model (VLIDORT) coupled with aerosol fields from GEOS-Chem. Section 4 compares the simulated UVAI values to observations from the Ozone Monitoring Instrument (OMI). The change in reflected solar radiation as observed by the UVAI tests the effective representation of the absorption of UV radiation by $\mathrm{BrC}$. Section 5 examines the effect of the added $\mathrm{BrC}$ absorption on ozone photolysis frequencies and tropospheric $\mathrm{OH}$ concentrations in the GEOSChem simulation. Section 6 calculates the DRE of absorbing brown carbon. Section 7 reports the conclusions.

\section{Observations}

\subsection{OMI ultraviolet aerosol index}

The OMI ultraviolet aerosol index is a method of detecting absorbing aerosols from satellite measurements in the nearUV wavelength region. The UVAI was first observed from the Nimbus-7 TOMS (Total Ozone Mapping Spectrometer) (Herman et al., 1997; Torres et al., 1998) and is currently a product of the OMI Near-UV algorithm (OMAERUV) (Torres et al., 2007). OMI flies on NASA's Aura satellite and has been taking global daily measurements since 2004. The OMAERUV algorithm uses the 354 and $388 \mathrm{~nm}$ radiances measured by OMI to calculate the UVAI according to Torres et al. (1998, 2007):

$\mathrm{UVAI}=-100 \log _{10}\left[\frac{I_{354}^{\text {meas }}}{I_{354}^{\text {calc }}\left(R_{354}^{*}\right)}\right]$,

where $I_{354}^{\text {meas }}$ is the TOA at $354 \mathrm{~nm}$ as measured by OMI, and $I_{354}^{\text {calc }}$ is the radiance at $354 \mathrm{~nm}$ calculated for a purely Rayleigh scattering atmosphere bounded by a Lambertian surface of reflectance $R_{354}^{*}$, which is known as the adjusted Lambert equivalent reflectivity (LER) (Dave, 1978). $R_{354}^{*}$ is calculated by correcting the LER at $388 \mathrm{~nm}\left(R_{388}^{*}\right)$ for the spectral dependence of the surface reflectance at $354 \mathrm{~nm}$.

Positive UVAI values indicate absorbing aerosol. Negative values indicate non-absorbing aerosol. Near-zero values indicate clouds, minimal aerosol, or other non-aerosol related effects such as unaccounted for land surface albedo wavelength dependence, ocean color effects or specular ocean reflection (i.e., sun glint). These second-order effects yield UVAI values \pm 0.5 within the noise level (Torres et al., 2007). The OMAERUV product identifies clouds using the measured scene reflectivity and the UVAI (Torres et al., 2013). We reject cloudy conditions (quality flag of 1 ) to focus on cloudfree conditions (quality flag 0).

In this work we use the OMI UVAI to evaluate simulated UVAI values, as described in Sect. 3.

\subsection{Absorption Ångström exponent (AAE)}

We use observations of the absorption Ångström exponent (AAE) for biomass burning aerosol to test our representation of the spectral dependence of absorption. The AAE is the slope of aerosol absorption optical depth (AAOD) versus wavelength $(\lambda)$ in log-log space. Using the AAE, the AAOD can be related to wavelength with the power-law relationship

$\mathrm{AAOD}=k \lambda^{-\mathrm{AAE}}$

where $k$ is a constant. Aerosols with spectrally independent absorption display an AAE of about 1, while aerosols with spectrally dependent absorption have an AAE $>1$. BC exhibits spectrally independent absorption, and is often accepted as having an AAE close to 1 (Bergstrom et al., 2002; Bond and Bergstrom, 2006). The observed AAE over the near-UV to near-IR spectral regions can indicate aerosol type, with urban pollution aerosols dominated by BC exhibiting an AAE near 1, biomass burning aerosols displaying an AAE near 2, and desert dust having an AAE > 2 (Bergstrom et al., 2007; Russell et al., 2010).

Several recent studies have attributed the spectrally dependent absorption by biomass burning aerosols to the presence of BrC (Clarke et al., 2007; Corr et al., 2012; Kirchstetter and Thatcher, 2012; Rizzo et al., 2011; Zhong and Jang, 2014). Kirchstetter et al. (2004) measured over the 300-1000 nm range an $\mathrm{AAE}$ of $\sim 2$ for biomass burning aerosol and an AAE of $\sim 1$ for motor vehicle aerosol. They found that after extracting the organic carbon from the samples using acetone, the AAE of the biomass burning aerosol decreased to around 1, while the motor vehicle aerosol AAE remained unchanged. They concluded that the spectral dependence of absorption by biomass burning aerosol was due to $\mathrm{BrC}$, while the absorption by motor vehicle emissions was due to $\mathrm{BC}$.

Table 1 contains a summary of measured AAE values for biomass burning aerosol. AAE values increase toward UV wavelengths as expected for $\mathrm{BrC}$ absorption. Variability in the AAE at visible wavelengths may reflect differences in burn conditions and fuel type. Observations in the ultraviolet, such as the UVAI, offer an exciting opportunity to exploit the large AAE of biomass burning aerosol at short wavelengths to assess the global magnitude of BrC absorption (Jethva and Torres, 2011).

\section{Simulated ultraviolet aerosol index}

We simulate the UVAI following Buchard et al. (2015) using the VLIDORT model (Spurr, 2006), which includes polarization effects and uses the discrete ordinates method to solve the radiative transfer equation. We supply VLIDORT with the OMI pixel viewing geometry to calculate the UVAI for that pixel. The UVAI values are calculated from TOA radiances computed by VLIDORT at 354 and $388 \mathrm{~nm}$, the wavelengths used by the OMAERUV product. 
Table 1. Absorption Ångström exponent (AAE) values for biomass burning regions from the literature.

\begin{tabular}{|c|c|c|c|}
\hline Wavelength (nm) & AAE value & Region & Reference \\
\hline \multicolumn{4}{|l|}{$350-400 \mathrm{~nm}$} \\
\hline $350-400$ & $2.5-3.0$ & South America & Jethva and Torres (2011) \\
\hline \multicolumn{4}{|l|}{$350-700 \mathrm{~nm}$} \\
\hline $360-700$ & 1.9 & Rural California & $\begin{array}{l}\text { Kirchstetter and } \\
\text { Thatcher (2012) }\end{array}$ \\
\hline \multicolumn{4}{|l|}{$450-550 \mathrm{~nm}$} \\
\hline $\begin{array}{l}470-532 \\
470-532\end{array}$ & $\begin{array}{l}1.9 \\
1.4 \\
\text { Mean } \pm \mathrm{SD}^{*} \\
\end{array}$ & $\begin{array}{l}\text { North-central Canada } \\
\text { “ }\end{array}$ & $\begin{array}{l}\text { Corr et al. (2012) } \\
\text { ، }\end{array}$ \\
\hline \multicolumn{4}{|l|}{$400-700 \mathrm{~nm}$} \\
\hline $\begin{array}{l}400-700 \\
440-670 \\
440-670 \\
440-670 \\
440-670 \\
470-660 \\
470-660 \\
470-660 \\
470-660\end{array}$ & $\begin{array}{l}1.5-1.9 \\
1.8 \\
1.3 \\
1.4 \\
1.6 \\
1.7 \\
1.3 \\
1.5 \\
2.1 \\
\text { Mean } \pm \mathrm{SD}\end{array}$ & $\begin{array}{l}\text { Laboratory } \\
\text { Boreal Forest } \\
\text { Southern Africa } \\
\text { South America } \\
\text { Amazon } \\
\text { Arctic } \\
\text { Arctic } \\
\text { Outside Beijing } \\
\text { North America }\end{array}$ & $\begin{array}{l}\text { Schnaiter et al. (2005) } \\
\text { Russell et al. (2010) } \\
\text { “ } \\
\text { “ } \\
\text { Corr et al. (2012) } \\
\text { “ } \\
\text { Yang et al. (2009) } \\
\text { Clarke et al. (2007) }\end{array}$ \\
\hline \multicolumn{4}{|l|}{$450-700 \mathrm{~nm}$} \\
\hline $470-660$ & 2.2 & North America & J. Liu et al. (2015) \\
\hline \multicolumn{4}{|l|}{$300-1000 \mathrm{~nm}$} \\
\hline $\begin{array}{l}325-1000 \\
325-1685 \\
330-1000 \\
370-950\end{array}$ & $\begin{array}{l}1.1 \\
1.5 \\
2 \\
1.5 \\
\text { Mean } \pm \text { SD } \\
\end{array}$ & $\begin{array}{l}\text { Southern Africa } \\
\text { Southern Africa } \\
\text { Southern Africa } \\
\text { Outside Beijing }\end{array}$ & $\begin{array}{l}\text { Bergstrom et al. (2007) } \\
\text { “ } \\
\text { Kirchstetter et al. (2004) } \\
\text { Yang et al. (2009) }\end{array}$ \\
\hline \multicolumn{4}{|l|}{$400-1000 \mathrm{~nm}$} \\
\hline $\begin{array}{l}440-870 \\
440-870 \\
440-870 \\
440-870 \\
440-1020 \\
440-1020 \\
440-1020 \\
440-1020 \\
450-950\end{array}$ & $\begin{array}{l}1.6 \\
1.3 \\
1.4 \\
1.4 \\
1.5 \\
1.3 \\
1.3 \\
1.4 \\
1.7 \\
\text { Mean } \pm \mathrm{SD}\end{array}$ & $\begin{array}{l}\text { Boreal Forest } \\
\text { Southern Africa } \\
\text { South America } \\
\text { Amazon } \\
\text { Boreal Forest } \\
\text { Southern Africa } \\
\text { South America } \\
\text { Amazon } \\
\text { Amazon }\end{array}$ & $\begin{array}{l}\text { Russell et al. (2010) } \\
\text { “ } \\
“ \\
\text { “ } \\
\text { “ } \\
\text { “ } \\
\text { Rizzo et al. (2011) }\end{array}$ \\
\hline
\end{tabular}

\footnotetext{
* SD: standard deviation
} 
Table 2. Imaginary part of the refractive index $(k)$ values for the base case with weakly absorbing "colorless" primary organic carbon.

\begin{tabular}{rr}
\hline Wavelength (nm) & Base case \\
\hline 300 & 0.008 \\
350 & 0.005 \\
400 & 0.005 \\
450 & 0.005 \\
500 & 0.005 \\
550 & 0.006 \\
\hline
\end{tabular}

Following Buchard et al. (2015) we calculate simulated UVAI values as

$\mathrm{UVAI}=-100 \log _{10}\left[\frac{I_{354}^{\mathrm{RAY}+\mathrm{AER}}}{I_{354}^{\mathrm{RAY}}\left(R_{354}^{*}\right)}\right]$,

where $I_{354}^{\mathrm{RAY}+\mathrm{AER}}$ is the TOA radiance calculated with VLIDORT at $354 \mathrm{~nm}$ assuming an atmosphere containing aerosol and Rayleigh effects, and $I_{354}^{\mathrm{RAY}}$ is the TOA radiance calculated with VLIDORT at $354 \mathrm{~nm}$ assuming a purely Rayleigh scattering atmosphere bounded by a Lambertian surface of reflectance $R_{354}^{*}$ (adjusted LER).

$R_{354}^{*}$ is calculated by correcting the LER at $388 \mathrm{~nm}\left(R_{388}^{*}\right)$ for wavelength dependence:

$R_{354}^{*}=R_{388}^{*}-\left(R_{388}-R_{354}\right)$,

where $R_{388}$ and $R_{354}$ are surface reflectance values from a revisited TOMS-based climatology data set (Torres et al., 2013).

$R_{388}^{*}$ is calculated by relating TOA radiance to diffuse reflectivity using the equation (Buchard et al., 2015)

$R_{388}^{*}=\frac{I_{388}^{\mathrm{RAY}+\mathrm{AER}}-I_{388}^{\mathrm{RAY}}}{T_{388}^{\mathrm{RAY}}+S_{b_{388}}^{\mathrm{RAY}}\left(I_{388}^{\mathrm{RAY}+\mathrm{AER}}-I_{388}^{\mathrm{RAY}}\right)}$,

where $I_{388}^{\mathrm{RAY}+\mathrm{AER}}$ is the TOA radiance calculated with VLIDORT at $388 \mathrm{~nm}$ assuming an atmosphere containing aerosol and Rayleigh effects, $I_{388}^{\mathrm{RAY}}$ is the TOA radiance at $388 \mathrm{~nm}$ calculated with VLIDORT for a purely Rayleigh scattering atmosphere bounded by a Lambertian surface, $T_{388}^{\mathrm{RAY}}$ is the simulated transmittance at $388 \mathrm{~nm}$ for a Rayleigh atmosphere, and $S_{b_{388}}^{\mathrm{RAY}}$ is the spherical albedo of a Rayleigh atmosphere at $388 \mathrm{~nm}$.

For the calculation of TOA radiances, we provide VLIDORT with vertical profiles of aerosol extinction, singlescattering albedo, and 32 Legendre-function expansion coefficients of the scattering phase function. We assume all aerosol particles are spherical. We obtain these aerosol optical properties using daily aerosol fields at satellite overpass time from GEOS-Chem version 9-01-03 (http://geos-chem. org), a global three-dimensional chemical transport model driven by assimilated meteorological data from the Goddard Earth Observation System (GEOS-5) of the NASA Global Modeling and Assimilation Office (GMAO). Our simulation is conducted at a spatial resolution of $2^{\circ} \times 2.5^{\circ}$ with 47 vertical levels for the year 2007.

GEOS-Chem contains a detailed oxidant-aerosol chemical mechanism (Bey et al., 2001; Park et al., 2004). The aerosol simulation includes the sulfate-nitrate-ammonium system (Fountoukis and Nenes, 2007; Park et al., 2004; Pye et al., 2009), primary carbonaceous aerosol (Park et al., 2003), mineral dust (Fairlie et al., 2007), and sea salt (Jaeglé et al., 2011). Aerosol optical properties are based on the Global Aerosol Data Set (GADS) (Koepke et al., 1997) as implemented by Martin et al. (2003), with updates for organics and secondary inorganics from aircraft observations (Drury et al., 2010), and for mineral dust (Lee et al., 2009; Ridley et al., 2012). Aerosols are treated as externally mixed. We treat the density of organic aerosol as $1.3 \mathrm{~g} \mathrm{~cm}^{-3}$ (Duplissy et al., 2011; Kuwata et al., 2012) and assume an organic aerosol mass to organic carbon fraction of 2.1 (Aiken et al., 2008; Canagaratna et al., 2015; Turpin and Lim, 2001).

Anthropogenic emissions are from the EDGAR v32FT2000 global inventory for 2000 (Olivier et al., 2005) with emissions overwritten in areas with regional inventories for the United States (NEI 2005), Mexico (BRAVO; Kuhns et al., 2005), Europe (EMEP; http://www.emep.int/), and East Asia (Zhang et al., 2009). Emissions are scaled to the year 2007 following emissions of related $\mathrm{CO}_{2}$ sources as described in van Donkelaar et al. (2008). Global biofuel emissions (Yevich and Logan, 2003), global anthropogenic emissions for carbonaceous aerosols (Bond et al., 2007; Leibensperger et al., 2012), and emissions from open fires for individual years from the GFED3 inventory (Mu et al., 2011) are included.

We calculate UVAI values for two cases. The base case simulation treats the aerosol optical properties as currently implemented in GEOS-Chem in which all organic carbon aerosols are weakly absorbing and colorless as shown in Table 2 . The second case adds the more strongly absorbing $\mathrm{BrC}$ as described in Sect. 4.2 below.

\section{Comparison of simulated and OMI UVAI}

\subsection{Base case simulation}

Figure 1 shows the monthly mean OMI UVAI observations for January, April, July, and September of 2007. Clear signals are apparent over regions dominated by mineral dust and biomass burning (Herman et al., 1997; Torres et al., 1998). Absorption over desert regions occurs for all four months, giving UVAI values between 1 and 3, particularly over the Saharan, Iranian, and Thar deserts. Aerosol absorption from biomass burning primarily follows the seasonal cycle of agricultural burning (Duncan et al., 2003). In January, absorp- 

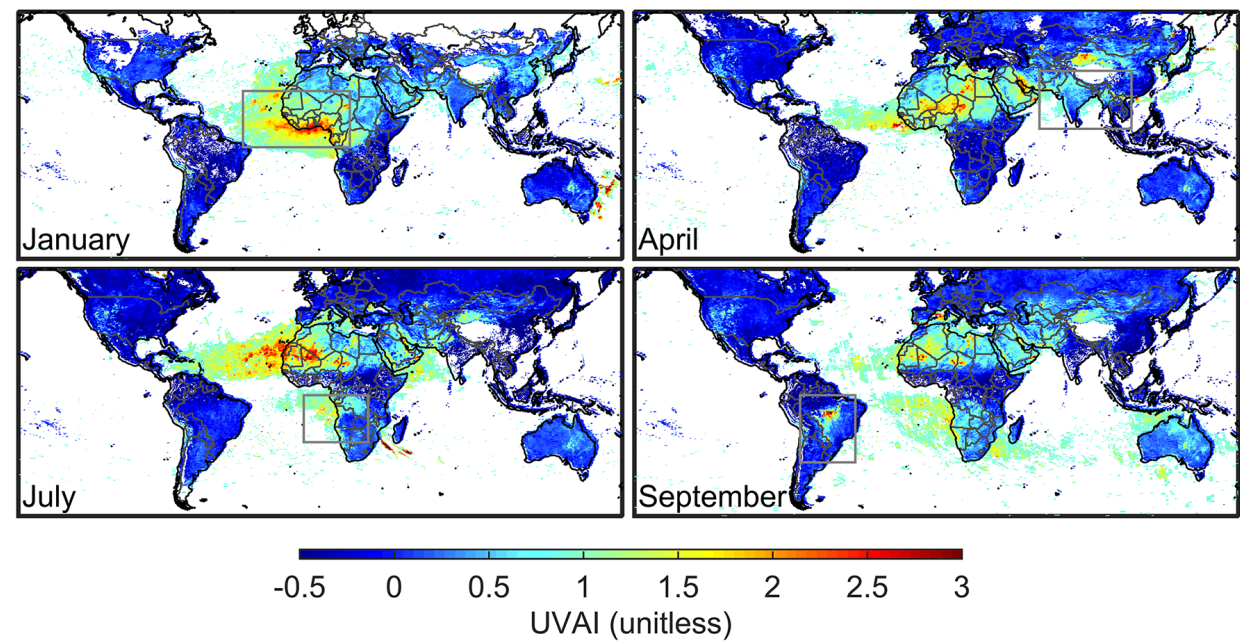

Figure 1. Monthly mean ultraviolet aerosol index (UVAI) observations from the OMI satellite instrument for 2007. White space indicates cloud or snow contamination. Gray boxes outline regions examined in Tables 3 and 4.
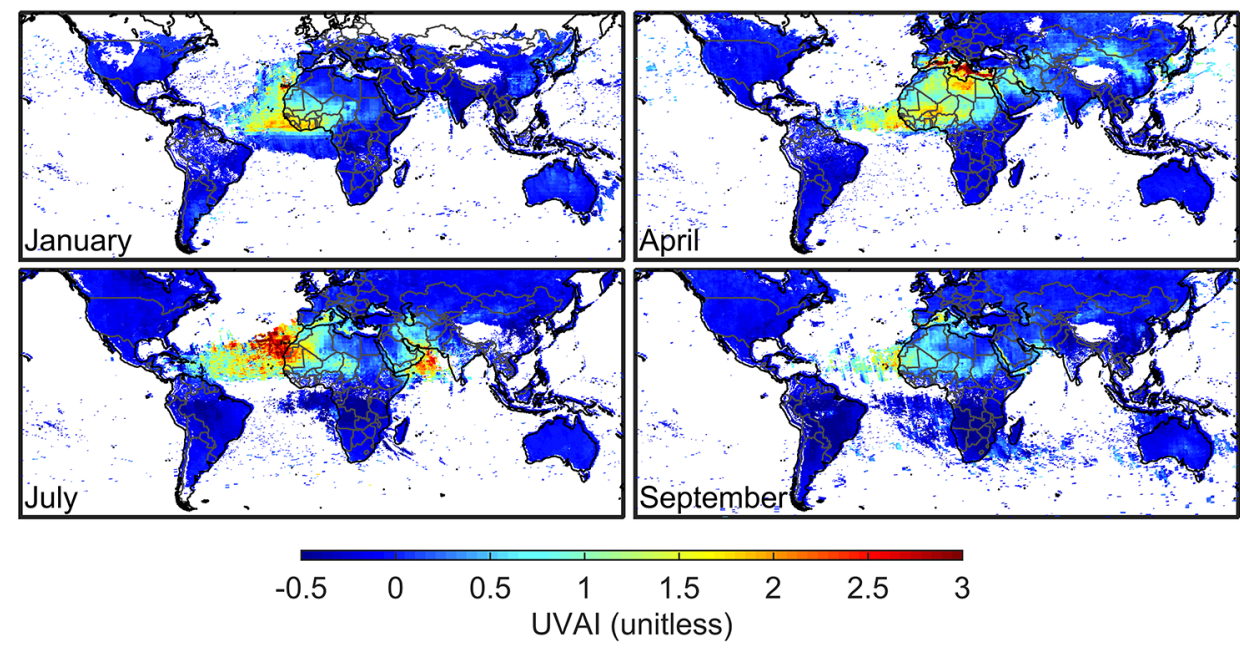

Figure 2. Monthly mean UVAI values for 2007 simulated for OMI observing conditions using the vector radiative transfer model VLIDORT coupled with GEOS-Chem aerosol fields for the base case without brown carbon (BrC). White indicates cloud or snow contamination.

tion over West Africa yields UVAI values between 1 and 2.5. In April aerosol absorption is visible over South Asia with UVAI values between 0.5 and 1 . UVAI values of $1-1.7$ occur over southern Africa in both July and September, while UVAI values of up to 3 occur over South America in September.

Figure 2 shows the monthly mean UVAI values for our base case simulation without $\mathrm{BrC}$, The simulation captures the major absorption features compared to OMI over the desert regions, giving UVAI values of $1-3$, however it fails to capture the absorption by biomass burning aerosol, giving UVAI values between -2 and 0 in all biomass burning regions for the four months. These negative values indicate that the UVAI simulation is insensitive to the absorption by $\mathrm{BC}$ and is dominated by the scattering from organic carbon aerosol. A sensitivity test with doubled BC concentrations increased UVAI values by only $\sim 0.1$. We also conducted a sensitivity test to determine whether the heights of the biomass burning plumes could explain the underestimated absorption. Raising the aerosol layer height to unrealistic altitudes ( $\sim 10 \mathrm{~km}$ above the surface) increased the UVAI by only $0.1-0.3$, which is insufficient to account for the differences between the simulation and observations.

To further analyze the discrepancies between simulated and observed UVAI, we choose four regions corresponding to the seasonal biomass burning outlined in Fig. 1: West Africa $\left(5^{\circ} \mathrm{S}-25^{\circ} \mathrm{N}, 40^{\circ} \mathrm{W}-20^{\circ} \mathrm{E}\right)$ in January, South Asia (5$\left.35^{\circ} \mathrm{N}, 60-110^{\circ} \mathrm{E}\right)$ in April, southern Africa $\left(0-30^{\circ} \mathrm{S}, 5^{\circ} \mathrm{W}-\right.$ $\left.30^{\circ} \mathrm{E}\right)$ in July, and South America $\left(0-40^{\circ} \mathrm{S}, 40-70^{\circ} \mathrm{W}\right)$ in September. Table 3 contains the correlation coefficients $(r)$ 
between the simulated and OMI UVAI as well as the mean bias (simulated-OMI UVAI). The correlation between the OMI and simulated UVAI is low (0.09-0.48) in all regions, with large mean biases of -0.32 to -0.97 .

Uncertainty in aerosol optical depth also cannot explain the UVAI bias. Table 4 shows the simulated AOD compared with AOD retrieved from the MODIS (Moderate Resolution Imaging Spectroradiometer) and MISR (Multi-angle Imaging Spectroradiometer) satellite instruments. Overall the simulated values are within the range of satellite-retrieved AOD values. The maximum difference in simulated versus satellite AOD is found with the MODIS Dark Target algorithm over South America in September. Matching the simulated AOD to the satellite AOD changed the UVAI by less than 0.1 .

We attempt to reconcile the differences between the simulated and OMI UVAI in biomass burning regions by introducing absorbing BrC into GEOS-Chem, as described below.

\subsection{Treatment of brown carbon}

Here we apply the OMI UVAI observations to estimate the effective absorption by BrC. We exploit the fact that the TOA radiances used in the OMI UVAI contain implicit information on the $\mathrm{BrC}$ from actual burn conditions, on the $\mathrm{BrC}$ that remains after chemical loss or evaporation, on Br-SOA, and on the $\mathrm{BrC} / \mathrm{POC}$ fraction. We use the term effective to denote the implicit dependence of the UVAI upon these multiple processes. Through sensitivity simulations, we derive the effective $k$ values for $\mathrm{BrC}$ given the assumed $\mathrm{BrC} / \mathrm{POC}$ fraction required to reproduce the observed absorption by the OMI UVAI. This is accomplished by conducting the sensitivity simulations for several cases of $\mathrm{BrC} / \mathrm{POC}$ fraction, assuming the same fixed spectral dependence for each case, and adjusting the magnitude of the effective $k$ values to match the OMI UVAI. We treat the relative spectral dependence of $k, \log (\Delta k) / \log (\Delta \lambda)$, as 3 for wavelengths between 300 and $600 \mathrm{~nm}$ to represent the mean from laboratory and field measurements of 3.2 \pm 0.7 (Kirchstetter et al., 2004; Zhang et al., 2013; Zhong and Jang, 2014). At wavelengths $\geq 600 \mathrm{~nm}$ we leave the absorption properties of POC unchanged since $\mathrm{BrC}$ absorption decreases significantly into the visible and nearIR (Bergstrom et al., 2007; Chen and Bond, 2010; Yang et al., 2009).

The filled circles in Fig. 3 show the effective $k$ values of $\mathrm{BrC}$ derived from seven sensitivity simulations that all achieve the same simulated UVAI. Only the BrC/POC fraction varies between simulations. The choice of simulated UVAI was selected to represent the global OMI UVAI over major biomass burning regions. The imaginary part of the refractive index decreases with increasing wavelength following an exponential relationship as prescribed based on laboratory and field measurements, and decreases with increasing $\mathrm{BrC} / \mathrm{POC}$ fraction as required to reproduce the OMI UVAI. The effective $k$ values increase with decreasing $\mathrm{BrC} / \mathrm{POC}$ fraction because as $\mathrm{BrC}$ concentration decreases, $\mathrm{BrC}$ must
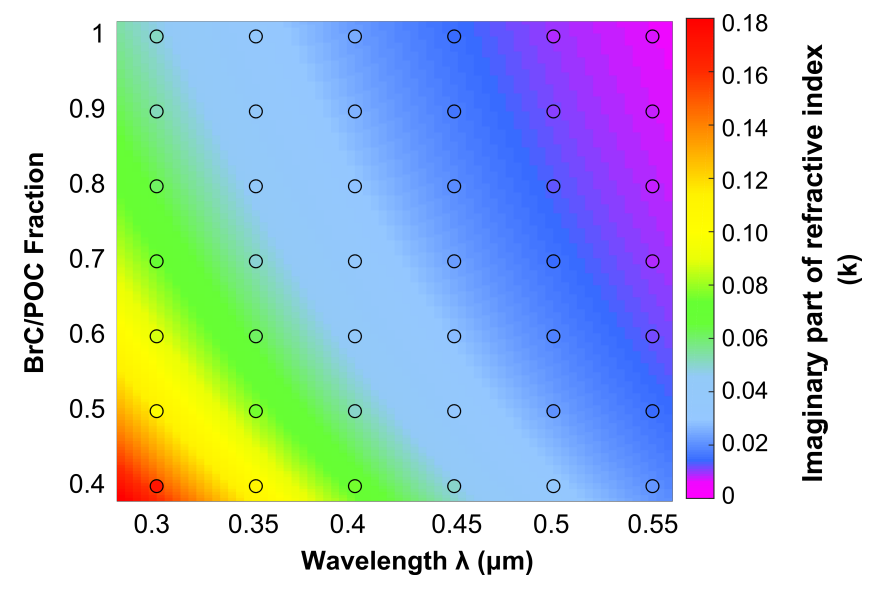

Figure 3. Imaginary part of the refractive index $(k)$ values inferred for $\mathrm{BrC}$ as a function of wavelength and of the assumed fraction of primary organic carbon that is brown $(\mathrm{BrC} / \mathrm{POC})$. The background spectrum represents $k$ values calculated using Eq. (6). The filled circles represent the $k$ values obtained from sensitivity simulations. An organic carbon density of $1.3 \mathrm{~g} \mathrm{~cm}^{-3}$ is assumed.

be more absorbing to match the absorption observed by OMI. Given the smoothly varying relationship between $k$ and $\mathrm{BrC} / \mathrm{POC}$ we develop the following expression to represent this relationship:

$$
\begin{gathered}
k=c \cdot \rho \cdot \lambda \cdot\left[35.4\left(\frac{\mathrm{BrC}}{\mathrm{POC}}\right)^{-1.25} \cdot \exp (-10.5 \lambda)\right] ; \\
\mathrm{BrC} / \mathrm{POC} \geq 0.4,300 \mathrm{~nm} \leq \lambda \leq 600 \mathrm{~nm},
\end{gathered}
$$

where $\lambda$ is wavelength $(\mu \mathrm{m}), \rho$ is the density of organic carbon $\left(\mathrm{g} \mu \mathrm{m}^{-3}\right)$, and $c$ is a conversion constant equal to $1.0 \times 10^{12} / 4 \pi \mu \mathrm{m}^{2} \mathrm{~g}^{-1}$.

The background spectrum of Fig. 3 shows the $k$ values calculated using Eq. (6). This expression reproduces the full radiative transfer sensitivity simulations with a root mean squared error (RMSE) of 0.004 and a coefficient of determination $\left(r^{2}\right)$ of 0.99 . Equation (6) does not apply for $\mathrm{BrC} / \mathrm{POC}$ fractions less than 0.4 since they do not reproduce the absorption observed by OMI. We emphasize that multiple choices of $k$ and $\mathrm{BrC} / \mathrm{POC}$ will yield the same TOA radiance and UVAI. The effects on tropospheric $\mathrm{OH}$ concentrations and radiative forcing remain unaffected as $\mathrm{BrC} / \mathrm{POC}$ and effective $k$ vary together, since the distribution of scattering and absorption remains the same.

Table 5 contains our derived imaginary parts of the refractive index for BrC/POC fractions of 0.5 and 1.0. Table 5 also contains effective $k$ values derived for an organic carbon density of $1.8 \mathrm{~g} \mathrm{~cm}^{-3}$ which has been assumed in prior studies of $\mathrm{BrC}$. The range of values for $k$ covered by varying the $\mathrm{BrC} / \mathrm{POC}$ fraction encompasses the range of values for $\mathrm{BrC}$ found in the literature (Chen and Bond, 2010; Feng et al., 2013; Kirchstetter et al., 2004; Lin et al., 2014; Sun et al., 2007; Wang et al., 2014; Zhang et al., 2013; Zhong 
Table 3. Comparison of the simulated versus observed (OMI) UVAI values for the biomass burning regions in the months examined. The base case corresponds to a simulation without $\mathrm{BrC}$, while case 2 corresponds to a simulation including absorbing $\mathrm{BrC}$.

\begin{tabular}{|c|c|c|c|c|c|c|c|}
\hline \multirow[b]{2}{*}{ Region $^{d}$} & \multirow[b]{2}{*}{$n^{\mathrm{c}}$} & \multirow[b]{2}{*}{ Month } & \multirow[b]{2}{*}{ Mean OMI UVAI } & \multicolumn{2}{|c|}{ Base case } & \multicolumn{2}{|c|}{ Case 2 with $\mathrm{BrC}$} \\
\hline & & & & $r^{\mathrm{a}}$ & Mean Bias ${ }^{b}$ & $r$ & Mean Bias \\
\hline West Africa & 381 & January & 1.25 & 0.48 & -0.57 & 0.68 & -0.09 \\
\hline South Asia & 280 & April & 0.34 & 0.46 & -0.32 & 0.66 & +0.0002 \\
\hline Southern Africa & 184 & July & 0.66 & 0.09 & -0.97 & 0.63 & -0.22 \\
\hline South America & 230 & September & 0.30 & 0.40 & -0.50 & 0.57 & +0.33 \\
\hline
\end{tabular}

Table 4. The mean AOD values for each region from the GEOS-Chem (GC) base case simulation, the MISR instrument, and the MODIS Terra satellite instrument. The MODIS values are included for both the collection 6 Deep Blue and Dark Target algorithms.

\begin{tabular}{lrrrr}
\hline & \multicolumn{4}{c}{ Mean AOD } \\
\cline { 2 - 5 } Region* & GC & MISR & MODIS Deep Blue & MODIS Dark Target \\
\hline West Africa & 0.42 & 0.42 & 0.45 & 0.51 \\
South Asia & 0.32 & 0.32 & 0.30 & 0.37 \\
Southern Africa & 0.19 & 0.19 & 0.13 & 0.24 \\
South America & 0.31 & 0.36 & 0.39 & 0.57 \\
\hline
\end{tabular}

* Regions are defined in Fig. 1.

and Jang, 2014). The four columns with BrC yield identical wavelength-dependent global distributions of scattering and absorption that in turn yield the same UVAI, OH, and DRE.

The columns with effective $k$ values for BrC/POC fraction of unity offer the convenience of representing the effective absorption by $\mathrm{BrC}$ without needing to assume an arbitrary $\mathrm{BrC} / \mathrm{POC}$ fraction, or to introduce a separate $\mathrm{BrC}$ tracer. The effective $k$ values for unity $\mathrm{BrC} / \mathrm{POC}$ fraction can be thought of as the effective imaginary refractive index for an internal mixture of $\mathrm{BrC}$ and colorless POC.

Evidence for the existence of brown secondary organic carbon (Br-SOA) also exists. The majority of $\mathrm{Br}-\mathrm{SOA}$ is from anthropogenic sources (Jo et al., 2015; Liu et al., 2013; P. F. Liu et al., 2015; Zhang et al., 2013), while SOA formed from biogenic carbon is largely non-absorbing (Flores et al., 2014; P. F. Liu et al., 2015). On a global scale it is estimated that the majority of SOA is formed from biogenic carbon (Hallquist et al., 2009; Lack et al., 2004; Tsigaridis and Kanakidou, 2003). Therefore we treat SOA as non-absorbing. We tested this approach in a sensitivity study with the standard SOA mechanism in GEOS-Chem v9-0103 (Henze and Seinfeld, 2006; Henze et al., 2008; Liao et al., 2007) by assigning $100 \%$ anthropogenic SOA as brown, and found that the change in UVAI was negligible (less than 0.1). Alternative SOA implementations (e.g., as used in Jo et al., 2015) may have a larger effect.

\subsection{Simulation including brown carbon}

Figure 4 shows the monthly mean UVAI values for the simulation including $\mathrm{BrC}$ for the months of January, April, July, and September of 2007. The simulated absorption features including $\mathrm{BrC}$ are much more consistent than the base case simulation at reproducing the OMI UVAI over biomass burning regions (Fig. 2). The simulated UVAI in the four biomass burning regions now ranges from 0.5 to 3 . As summarized in Table 3, the correlation coefficients between the simulated and OMI UVAI for the four biomass burning regions now range from 0.57 to 0.68 , with mean biases of -0.22 to +0.33 .

The simulated UVAI using global mean $k$ values underestimates the OMI observations for the West Africa and southern Africa regions, but overestimates observations in the South American region. We tested how $k$ would need to change to explain the regional UVAI bias if $k$ were the only error source. We find that these regional biases could be eliminated by changing $k$ at $350 \mathrm{~nm}$ by $+2 \%$ over West Africa, by $+10 \%$ over southern Africa, and by $-30 \%$ over South America. The presence of more absorbing $\mathrm{BrC}$ over West and southern Africa where savannah fires dominate, and less absorbing $\mathrm{BrC}$ over the South America region where forest fires dominate, is consistent with work by Saleh et al. (2014) who found that the absorptivity of $\mathrm{BrC}$ from biomass burning is greater for flaming fires associated with burning grasslands than for smouldering fires associated with burning forest.

The absorption in the West and southern Africa cases appears to be concentrated closer to the source for the simu- 
Table 5. Imaginary part of the refractive index $(k)$ values for brown carbon (not total organic carbon) inferred for case 2 . We include $k$ values associated with multiple densities $(\rho)$, and multiple fractions of brown carbon to primary organic carbon (BrC/POC). All four columns for case 2 yield the same absorption.

\begin{tabular}{rrrrrr}
\hline & \multicolumn{2}{c}{ Case 2 with $\operatorname{BrC}\left(\rho=1.3 \mathrm{~g} \mathrm{~cm}^{-3}\right)$} & & \multicolumn{2}{c}{ Case 2 with $\operatorname{BrC}\left(\rho=1.8 \mathrm{~g} \mathrm{~cm}^{-3}\right)$} \\
\cline { 2 - 3 } Wavelength $(\mathrm{nm})$ & $\mathrm{BrC} / \mathrm{POC}=0.50$ & $\mathrm{BrC} / \mathrm{POC}=1.0$ & & $\mathrm{BrC} / \mathrm{POC}=0.50$ & $\mathrm{BrC} / \mathrm{POC}=1.0$ \\
\hline 300 & 0.11 & 0.051 & & 0.16 & 0.071 \\
350 & 0.077 & 0.037 & & 0.11 & 0.051 \\
400 & 0.052 & 0.025 & & 0.073 & 0.035 \\
450 & 0.035 & 0.014 & & 0.049 & 0.019 \\
500 & 0.023 & 0.009 & & 0.021 & 0.013 \\
550 & 0.015 & & & & 0.010 \\
\hline
\end{tabular}

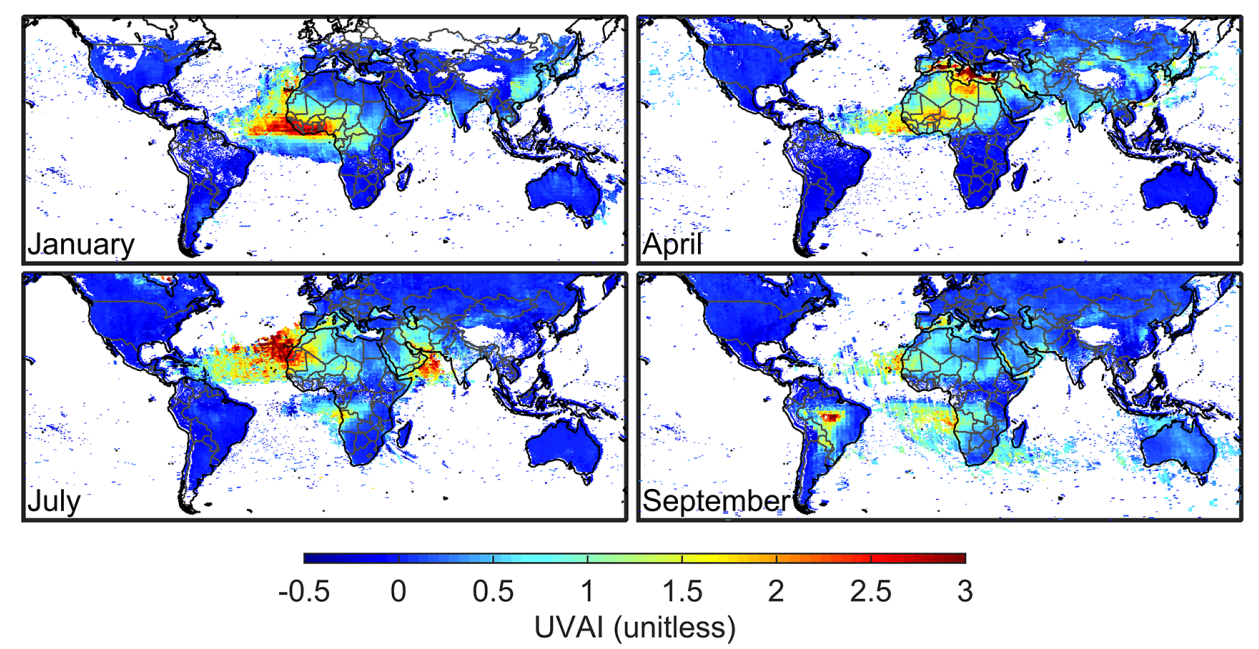

Figure 4. Monthly mean UVAI values for 2007 simulated for OMI observing conditions using the vector radiative transfer model VLIDORT coupled with GEOS-Chem aerosol fields for case 2, which assumes the presence of absorbing BrC aerosol. White indicates clouds or snow contamination.

lated values (Fig. 4) compared to the OMI values (Fig. 1), which show an even distribution of UVAI values away from the source. By contrast, the absorption in the South American region appears to be distributed farther from the source in the simulation than in the OMI observations. Evidence exists of atmospheric photochemical loss and evaporation of $\mathrm{BrC}$ that causes it to become less absorbing over a lifetime of less than a day (Forrister et al., 2015; Zhong and Jang, 2014). Representing these processes would improve the simulation in the South American region but degrade the simulation in the West Africa and southern Africa regions. Regional treatment of BrC loss processes may be warranted in future work. The current implementation offers our best representation of the effective BrC absorption at the global scale.

Table 6 shows the calculated AAE values for biomass burning aerosol (i.e., black carbon + organic carbon aerosol) from our simulations for comparison with the literature values in Table 1. Large biases are apparent for the base case simulation without $\mathrm{BrC}$. We evaluate the case 2 simulation including $\mathrm{BrC}$ in detail. For the $350-400 \mathrm{~nm}$ wave- length region our mean AAE value of $2.8 \pm 0.22$ for the four biomass burning regions is within the recommended values of 2.5-3.0 by Jethva and Torres (2011). In the 350-700 nm range our mean AAE of $2.2 \pm 0.17$ is close to the value of 1.9 from Kirchstetter and Thatcher (2012). The slight positive bias could arise from the fact that Kirchstetter and Thatcher (2012) took their absorption measurements from wood smoke emitted from houses in rural California during the winter, which have different conditions than the tropical open burning considered here. We obtain a mean AAE value of $1.7 \pm 0.15$ for the $300-1000 \mathrm{~nm}$ range, which falls within the literature values of $1.1-2$. For the $450-550 \mathrm{~nm}$ wavelength region, we obtain a mean AAE value of $2.5 \pm 0.14$, which is biased high compared to the values from Corr et al. (2012) extracted from an examination of biomass burning plumes in North-Central Canada, where burn conditions differ from the mostly tropical regions considered in our analysis. Over the $400-700 \mathrm{~nm}$ region we obtain a mean AAE of $2.1 \pm 0.15$, falling within the range of the literature values (1.3-2.1). In the $400-1000 \mathrm{~nm}$ region, we obtain a mean 
Table 6. The absorption Ångström exponent (AAE) values for major biomass burning regions and seasons obtained from the base case simulation without $\mathrm{BrC}$ and the case 2 simulation including absorbing $\mathrm{BrC}$.

\begin{tabular}{|c|c|c|c|c|c|}
\hline $\begin{array}{r}\text { Wavelength } \\
(\mathrm{nm})\end{array}$ & $\begin{array}{r}\text { January } \\
\text { (West Africa) }\end{array}$ & $\begin{array}{r}\text { April } \\
\text { (South Asia) }\end{array}$ & $\begin{array}{r}\text { July } \\
\text { (Southern Africa) }\end{array}$ & $\begin{array}{r}\text { September } \\
\text { (South America) }\end{array}$ & Mean $\pm \mathrm{SD}^{*}$ \\
\hline \multicolumn{6}{|c|}{ Base case } \\
\hline $350-400$ & 1.2 & 1.2 & 1.2 & 1.2 & $1.2 \pm 0.00$ \\
\hline $350-700$ & 1.0 & 1.2 & 1.0 & 1.1 & $1.1 \pm 0.09$ \\
\hline $450-550$ & 0.8 & 1.1 & 0.7 & 1.0 & $0.9 \pm 0.18$ \\
\hline $400-700$ & 1.0 & 1.2 & 0.9 & 1.1 & $1.1 \pm 0.13$ \\
\hline $450-700$ & 1.0 & 1.1 & 0.9 & 1.0 & $1.0 \pm 0.08$ \\
\hline $300-1000$ & 0.9 & 1.1 & 0.9 & 0.9 & $0.9 \pm 0.10$ \\
\hline $400-1000$ & 0.7 & 0.9 & 0.7 & 0.7 & $0.8 \pm 0.10$ \\
\hline \multicolumn{6}{|c|}{ Case 2 with $\mathrm{BrC}$} \\
\hline $350-400$ & 2.9 & 2.5 & 3 & 2.9 & $2.8 \pm 0.22$ \\
\hline $350-700$ & 2.3 & 2 & 2.4 & 2.3 & $2.2 \pm 0.17$ \\
\hline $450-550$ & 2.5 & 2.3 & 2.6 & 2.6 & $2.5 \pm 0.14$ \\
\hline $400-700$ & 2.2 & 1.9 & 2.2 & 2.2 & $2.1 \pm 0.15$ \\
\hline $450-700$ & 1.9 & 1.7 & 1.9 & 1.9 & $1.8 \pm 0.10$ \\
\hline $300-1000$ & 1.8 & 1.6 & 1.8 & 1.8 & $1.7 \pm 0.15$ \\
\hline $400-1000$ & 1.3 & 1.3 & 1.3 & 1.3 & $1.3 \pm 0.00$ \\
\hline
\end{tabular}

* SD: standard deviation.

AAE value of $1.3 \pm 0.005$, which is at the low end of the literature values (1.3-1.7). The overall consistency between observed and simulated AAE provides a measure of confidence in the spectral dependence of aerosol optical properties from the UV to the IR. We now examine the implications of this absorption for $\mathrm{OH}$ and DRE.

\section{Analysis of the effect of absorption by $\mathrm{BrC}$ on $\mathrm{OH}$ concentrations in GEOS-Chem}

The strong absorption in the UV by $\mathrm{BrC}$ aerosol decreases photolysis frequencies, which has implications for ozone photolysis and $\mathrm{OH}$ production. Here we examine the effect of the added absorption by $\mathrm{BrC}$ on the $\mathrm{O}^{3} \rightarrow \mathrm{O}\left({ }^{1} \mathrm{D}\right)$ photolysis frequency, $J\left(\mathrm{O}\left({ }^{1} \mathrm{D}\right)\right)$, and tropospheric $\mathrm{OH}$ concentrations.

Figure 5 shows the percent differences in lowertropospheric $\mathrm{OH}$ concentrations between the GEOS-Chem simulation including absorbing $\mathrm{BrC}$ versus the base case simulation. The most significant decreases correspond with the major biomass burning regions. The addition of $\mathrm{BrC}$ decreases $\mathrm{OH}$ concentrations by up to $30 \%$ over the South American biomass burning region in September and up to $20 \%$ over the southern Africa biomass burning region in July. OH concentrations decrease by up to $15 \%$ over West Africa in January and southern Africa in September, with decreases of up to $5 \%$ over North America in July, South America in July, and South Asia in January, April, and September. The spatial and seasonal pattern of $J\left(\mathrm{O}^{1}(\mathrm{D})\right)$ differ- ences closely reproduces the changes in $\mathrm{OH}\left(r^{2}=0.85\right)$ (not shown).

Methyl chloroform observations provide a valuable constraint on global OH (Prather et al., 2012; Spivakovsky et al., 2000). The addition of BrC to the GEOS-Chem simulation reduces global mean tropospheric $\mathrm{OH}$ concentrations. The reduction in global mean $\mathrm{OH}$ concentrations increases the methyl chloroform lifetime to tropospheric $\mathrm{OH}$ from 5.62 to 5.68 years. This change is noteworthy given the buffered nature of $\mathrm{OH}$. This change reduces the bias with observations giving a methyl chloroform lifetime of $6.0(+0.5,-0.4)$ years (Prinn et al., 2005).

\section{Radiative impact of brown carbon}

We calculate the direct radiative effect (DRE) of including absorbing $\mathrm{BrC}$ relative to that of the base case simulation. We use GEOS-Chem coupled with the radiative transfer model RRTMG (Iacono et al., 2008), a configuration known as GCRT, that is described in Heald et al. (2014). GC-RT calculates both the longwave (LW) and shortwave (SW) instantaneous total radiative fluxes as well as the flux differences due to a specific constituent of the atmosphere (e.g., organic aerosol). The DRE is calculated by adding the LW and SW flux differences determined through perturbation of the constituent of interest. Our GC-RT simulations use version 10.1 of GEOSChem with the same aerosol emissions described in Sect. 3 (e.g., GFED3 open fire emissions). We calculate the DRE of absorption by $\mathrm{BrC}$ as the difference in the DRE of organic 


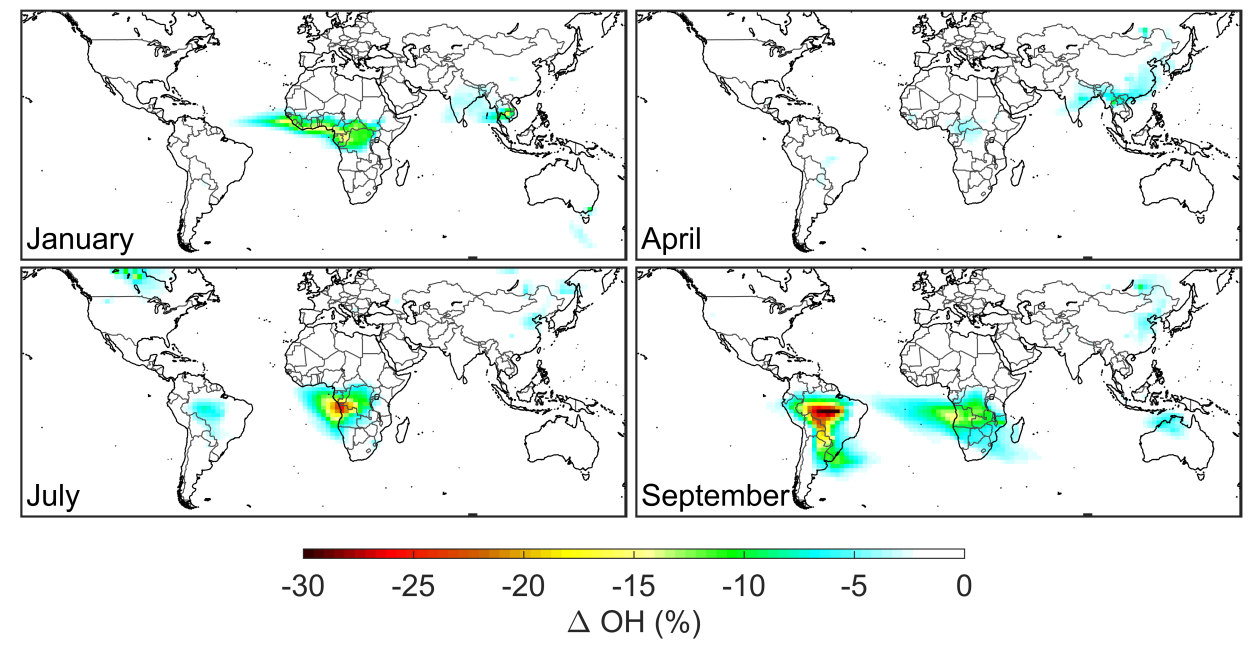

Figure 5. Percent difference between $\mathrm{OH}$ concentrations in the lower troposphere from a GEOS-Chem simulation including absorbing BrC minus a simulation without BrC. The values are monthly means for January, April, July, and September 2007.

aerosol when including $\mathrm{BrC}$ (case 2) minus the DRE of organic aerosol in the base case. We focus on the DRE rather than the DRF to avoid ambiguity in preindustrial BrC.

Figure 6 shows all-sky DRE values for 2007. The top two panels are the DRE values for organic aerosol from the case 2 simulation including $\mathrm{BrC}$. The overall DRE of organic aerosol including $\mathrm{BrC}$ is negative, with the largest effects over major biomass burning regions. The bottom two panels show the DRE for absorption by $\mathrm{BrC}$, calculated as the difference between the DRE of organic aerosol for the case 2 simulation including $\mathrm{BrC}$ minus the base case simulation. At the surface $\mathrm{BrC}$ absorption reduces the DRE by $-1.5 \mathrm{~W} \mathrm{~m}^{-2}$ over South America and southern Africa, and by -0.5 to $-0.25 \mathrm{~W} \mathrm{~m}^{-2}$ over South Asia, North America, West Africa, Australia, and Europe. At TOA, BrC absorption increases the DRE by up to $0.3 \mathrm{~W} \mathrm{~m}^{-2}$ over South America and southern Africa, and by 0.05 to $0.15 \mathrm{~W} \mathrm{~m}^{-2}$ over broad regions. This overall cooling effect at the surface and warming effect on the atmosphere are consistent with previous work (e.g., Chen and Bond, 2010).

Table 7 contains LW and SW global annual mean flux differences as well as the resulting DRE values for both organic aerosol and $\mathrm{BrC}$ absorption. The values for organic aerosol are from the base case simulation assuming weakly absorbing organic carbon and the case 2 simulation including $\mathrm{BrC}$, while the values for $\mathrm{BrC}$ absorption are calculated as their difference. Absorption by $\mathrm{BrC}$ has a mean all-sky DRE at TOA of $+0.03 \mathrm{~W} \mathrm{~m}^{-2}$ and at the surface of $-0.08 \mathrm{~W} \mathrm{~m}^{-2}$.

Our findings are at the lower end of the range of values from other studies that estimate the DRE of BrC absorption. Feng et al. (2013) introduce absorption by $\mathrm{BrC}$ based on the optical properties from Kirchstetter et al. (2004) and Chen and Bond (2010) into a global model, and calculate an allsky TOA DRE for BrC absorption of +0.04 to $+0.11 \mathrm{~W} \mathrm{~m}^{-2}$, and an all-sky surface DRE for $\mathrm{BrC}$ absorption of -0.06 to $-0.14 \mathrm{~W} \mathrm{~m}^{-2}$. Chung et al. (2012) estimate BrC absorption by subtracting the absorption by $\mathrm{BC}$ and desert dust from total aerosol AAE values from AERONET to calculate an allsky TOA DRE for organic aerosol when including $\mathrm{BrC}$ between -0.15 and $+0.12 \mathrm{~W} \mathrm{~m}^{-2}$ and an all-sky surface DRE between -1.50 and $-0.75 \mathrm{~W} \mathrm{~m}^{-2}$. Arola et al. (2015) use AERONET retrieved imaginary parts of the refractive index for $\mathrm{BrC}$ at $440,670,870$, and $1020 \mathrm{~nm}$ to estimate over the Indo-Gangetic plain monthly all-sky TOA DRE values for organic aerosol including $\mathrm{BrC}$ absorption up to $+0.5 \mathrm{~W} \mathrm{~m}^{-2}$ in spring and as low as $-1 \mathrm{~W} \mathrm{~m}^{-2}$ in the winter.

\section{Conclusions}

We interpret OMI observations of the ultraviolet aerosol index (UVAI), which provides a measure of absorbing aerosols, by developing a simulation of the UVAI using the vector radiative transfer model VLIDORT coupled with GEOS-Chem aerosol fields. The base case simulation without brown carbon $(\mathrm{BrC})$ well represents the observed UVAI in most of the world but significantly underestimates the absorption in biomass burning regions. We apply the OMI UVAI to estimate absorption by $\mathrm{BrC}$. This approach exploits the strong absorption by $\mathrm{BrC}$ at ultraviolet wavelengths and its effect on top of atmosphere (TOA) radiance. We express the imaginary part of the refractive index of $\mathrm{BrC}$ that is required to obtain near-identical TOA radiance values as a function of the fraction of primary organic carbon that is brown. This effective refractive index of $\mathrm{BrC}$ provides a measure of the degree of browness needed to represent the complex processes (e.g., burn conditions, photochemical loss) affecting global $\mathrm{BrC}$ and in turn the UVAI. This effective refractive index of $\mathrm{BrC}$ eliminates the need to know the $\mathrm{BrC} / \mathrm{POC}$ ratio to model 

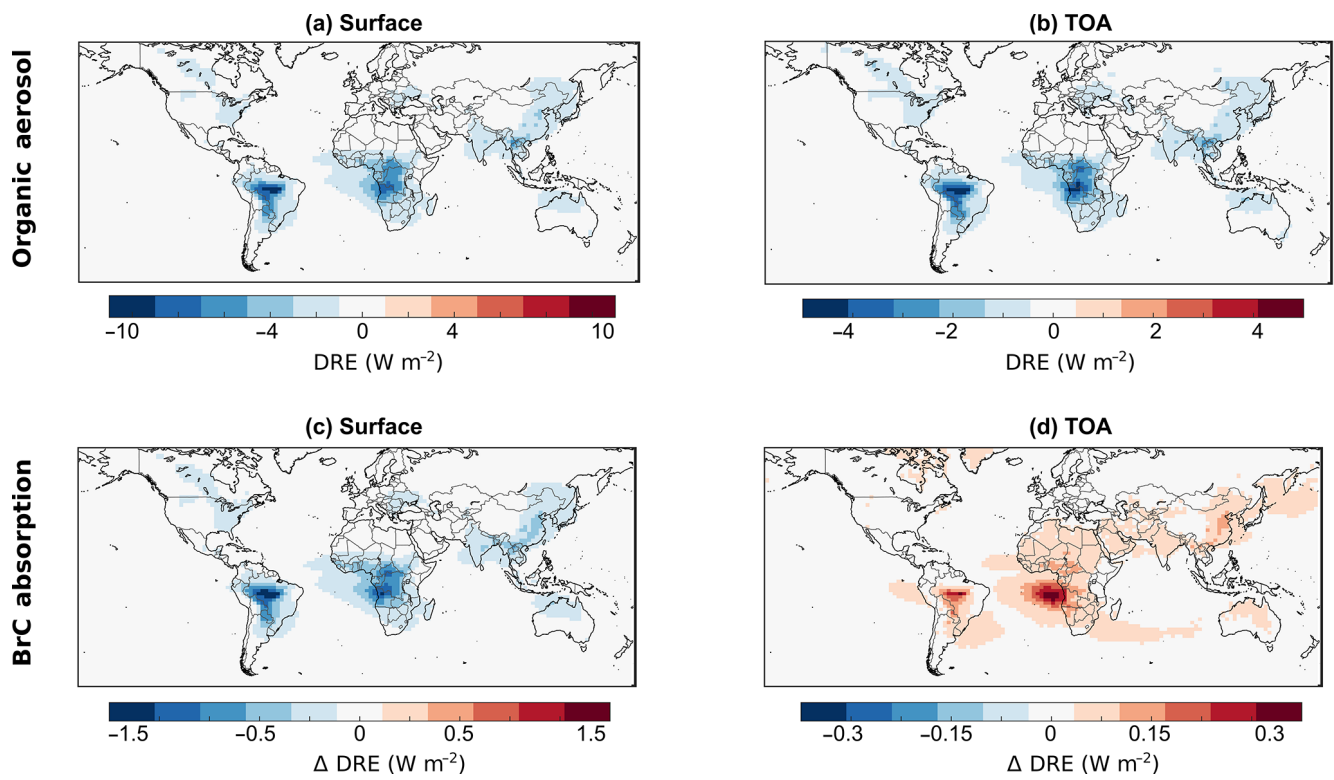

Figure 6. Annual mean all-sky DRE values for $2007\left(\mathrm{~W} \mathrm{~m}^{-2}\right)$. The top two panels are the DRE values for organic aerosol from the case 2 simulation including $\mathrm{BrC}$ at (a) the surface and (b) TOA. The bottom two panels are the change in DRE values for absorption by BrC calculated as the difference between the DRE values for organic aerosol from the case 2 simulation and the base case simulation (without $\mathrm{BrC})$ at (c) the surface and (d) TOA.

Table 7. Global annual mean LW and SW flux differences and resulting DRE values for 2007 at TOA and the surface. The values for organic aerosol are shown for both the base case simulation without $\mathrm{BrC}$ and the case 2 simulation including absorbing brown carbon. The DRE values for $\mathrm{BrC}$ absorption are calculated as the difference between the DRE of organic aerosol from case 2 minus the base case.

\begin{tabular}{lrrr}
\hline & \multicolumn{2}{c}{ Organic aerosol } & BrC absorption \\
& Base case & Case 2 & Case 2 - Base case \\
\hline TOA DRE, clear sky $\left(\mathrm{W} \mathrm{m}^{-2}\right)$ & -0.33 & -0.31 & +0.02 \\
LW & +0.0026 & +0.0028 & \\
SW & -0.33 & -0.31 & +0.03 \\
\hline TOA DRE, all sky $\left(\mathrm{W} \mathrm{m}^{-2}\right)$ & -0.24 & -0.21 & \\
LW & +0.0020 & +0.0021 & -0.09 \\
SW & -0.24 & -0.21 & \\
\hline Surface DRE, clear sky $\left(\mathrm{W} \mathrm{m}^{-2}\right)$ & -0.50 & -0.60 & -0.08 \\
LW & +0.0061 & +0.0067 & \\
SW & -0.51 & -0.61 & \\
\hline Surface DRE, all sky $\left(\mathrm{W} \mathrm{m}^{-2}\right)$ & -0.41 & -0.49 & \\
LW & +0.0051 & +0.0056 & \\
SW & -0.42 & -0.5 & \\
\hline
\end{tabular}

the radiative effects of BrC. Rather, an effective refractive index can be chosen (Eq. 6) to represent an internal mixture of $\mathrm{BrC}$ and colorless POC.

The simulation including absorbing $\mathrm{BrC}$ is much more consistent than the base case at reproducing the OMI UVAI over biomass burning regions. The mean bias between simulated and OMI UVAI values is reduced from -0.57 to -0.09 over West Africa in January, from -0.32 to +0.0002 over South Asia in April, from -0.97 to -0.22 over southern
Africa in July, and from -0.50 to +0.33 over South America in September. The updated optical properties for $\mathrm{BrC}$ result in AAE values for biomass burning aerosol ranging from 2.9 in the UV to 1.3 across the UV-Near IR, which are broadly consistent with field observations.

We apply this constraint on ultraviolet absorption to examine implications for the $\mathrm{O}_{3} \rightarrow \mathrm{O}\left({ }^{1} \mathrm{D}\right)$ photolysis frequency. We find that the inclusion of absorbing $\mathrm{BrC}$ into GEOSChem decreases $J\left(\mathrm{O}\left({ }^{1} \mathrm{D}\right)\right)$ and lower tropospheric $\mathrm{OH}$ by 
up to $30 \%$ over South America in September, up to $20 \%$ over southern Africa in July, up to $15 \%$ over West Africa in January and southern Africa in September, and up to $5 \%$ elsewhere. The decrease in global mean $\mathrm{OH}$ concentration in GEOS-Chem increases the methyl chloroform lifetime to tropospheric $\mathrm{OH}$ from 5.62 to 5.68 years, reducing the bias with estimates from observations of $6.0(+0.5,-0.4)$ years.

We calculate the direct radiative effect (DRE) of BrC using GEOS-Chem coupled with the radiative transfer model RRTMG (GC-RT). We obtain global annual mean all-sky TOA DRE values for BrC absorption of $+0.03 \mathrm{~W} \mathrm{~m}^{-2}$ and values of $-0.08 \mathrm{~W} \mathrm{~m}^{-2}$ at the surface. Regional changes of up to $+0.3 \mathrm{~W} \mathrm{~m}^{-2}$ at TOA and down to $-1.5 \mathrm{~W} \mathrm{~m}^{-2}$ at the surface are found over major biomass burning regions. Our results are within the range of prior estimates of DRE for $\mathrm{BrC}$ absorption.

Ample opportunities exist to further develop the simulations of BrC and more generally of the UVAI. These opportunities include explicitly accounting for the range of processes affecting BrC such as burn conditions, photochemical loss, secondary production, as well as regional treatment of BrC. An explicit simulation of $\mathrm{BrC}$ (e.g., Jo et al., 2015) would facilitate these developments. Interpretation of the long observational record of the UVAI from 1979 to the present should offer constraints on trends in aerosol composition, ultraviolet absorption, and radiative effects. The forthcoming TROPOMI instrument and geostationary constellation (e.g., TEMPO, Sentinel-4, and GEMS) will offer UVAI observations at 5-20 times higher spatial resolution, as well as information on diurnal variation, both of which may offer additional constraints on $\mathrm{BrC}$ evolution.

Acknowledgements. This work was supported by the Natural Science and Engineering Research Council of Canada. Computational facilities were provided in part by the Atlantic Computational Excellence Network consortium of Compute Canada. We thank Farhan Khan for assistance during the early stages of this work.

Edited by: M. K. Dubey

\section{References}

Aiken, A. C., DeCarlo, P. F., Kroll, J. H., Worsnop, D. R., Huffman, J. A., Docherty, K. S., Ulbrich, I. M., Mohr, C., Kimmel, J. R., Sueper, D., Sun, Y., Zhang, Q., Trimborn, A., Northway, M., Ziemann, P. J., Canagaratna, M. R., Onasch, T. B., Alfarra, M. R., Prevot, A. S. H., Dommen, J., Duplissy, J., Metzger, A., Baltensperger, U. and Jimenez, J. L.: O/C and OM/OC Ratios of Primary, Secondary, and Ambient Organic Aerosols with HighResolution Time-of-Flight Aerosol Mass Spectrometry, Environ. Sci. Technol., 42, 4478-4485, doi:10.1021/es703009q, 2008.

Andreae, M. O. and Gelencsér, A.: Black carbon or brown carbon? The nature of light-absorbing carbonaceous aerosols, Atmos. Chem. Phys., 6, 3131-3148, doi:10.5194/acp-6-3131-2006, 2006.
Arola, A., Schuster, G., Myhre, G., Kazadzis, S., Dey, S., and Tripathi, S. N.: Inferring absorbing organic carbon content from AERONET data, Atmos. Chem. Phys., 11, 215-225, doi:10.5194/acp-11-215-2011, 2011.

Arola, A., Schuster, G. L., Pitkänen, M. R. A., Dubovik, O., Kokkola, H., Lindfors, A. V., Mielonen, T., Raatikainen, T., Romakkaniemi, S., Tripathi, S. N., and Lihavainen, H.: Direct radiative effect by brown carbon over the Indo-Gangetic Plain, Atmos. Chem. Phys., 15, 12731-12740, doi:10.5194/acp-1512731-2015, 2015.

Bergstrom, R. W., Russell, P. B., and Hignett, P.: Wavelength Dependence of the Absorption of Black Carbon Particles: Predictions and Results from the TARFOX Experiment and Implications for the Aerosol Single Scattering Albedo, J. Atmos. Sci., 59, 567-577, doi:10.1175/15200469(2002)059<0567:WDOTAO>2.0.CO;2, 2002.

Bergstrom, R. W., Pilewskie, P., Russell, P. B., Redemann, J., Bond, T. C., Quinn, P. K., and Sierau, B.: Spectral absorption properties of atmospheric aerosols, Atmos. Chem. Phys., 7, 5937-5943, doi:10.5194/acp-7-5937-2007, 2007.

Bey, I., Jacob, D. J., Yantosca, R. M., Logan, J. A., Field, B. D., Fiore, A. M., Li, Q., Liu, H. Y., Mickley, L. J., and Schultz, M. G.: Global modeling of tropospheric chemistry with assimilated meteorology: Model description and evaluation, J. Geophys. Res., 106, 23073, doi:10.1029/2001JD000807, 2001.

Bond, T. C.: Spectral dependence of visible light absorption by carbonaceous particles emitted from coal combustion, Geophys. Res. Lett., 28, 4075-4078, doi:10.1029/2001GL013652, 2001.

Bond, T. C. and Bergstrom, R. W.: Light Absorption by Carbonaceous Particles: An Investigative Review, Aerosol Sci. Technol., 40, 27-67, doi:10.1080/02786820500421521, 2006.

Bond, T. C., Bhardwaj, E., Dong, R., Jogani, R., Jung, S., Roden, C., Streets, D. G., and Trautmann, N. M.: Historical emissions of black and organic carbon aerosol from energy-related combustion, 1850-2000, Global Biogeochem. Cy., 21, GB2018, doi:10.1029/2006GB002840, 2007.

Bond, T. C., Doherty, S. J., Fahey, D. W., Forster, P. M., Berntsen, T., DeAngelo, B. J., Flanner, M. G., Ghan, S., Kärcher, B., Koch, D., Kinne, S., Kondo, Y., Quinn, P. K., Sarofim, M. C., Schultz, M. G., Schulz, M., Venkataraman, C., Zhang, H., Zhang, S., Bellouin, N., Guttikunda, S. K., Hopke, P. K., Jacobson, M. Z., Kaiser, J. W., Klimont, Z., Lohmann, U., Schwarz, J. P., Shindell, D., Storelvmo, T., Warren, S. G., and Zender, C. S.: Bounding the role of black carbon in the climate system: A scientific assessment, J. Geophys. Res. Atmos., 118, 5380-5552, doi:10.1002/jgrd.50171, 2013.

Buchard, V., da Silva, A. M., Colarco, P. R., Darmenov, A., Randles, C. A., Govindaraju, R., Torres, O., Campbell, J., and Spurr, R.: Using the OMI aerosol index and absorption aerosol optical depth to evaluate the NASA MERRA Aerosol Reanalysis, Atmos. Chem. Phys., 15, 5743-5760, doi:10.5194/acp-15-57432015, 2015.

Canagaratna, M. R., Jimenez, J. L., Kroll, J. H., Chen, Q., Kessler, S. H., Massoli, P., Hildebrandt Ruiz, L., Fortner, E., Williams, L. R., Wilson, K. R., Surratt, J. D., Donahue, N. M., Jayne, J. T., and Worsnop, D. R.: Elemental ratio measurements of organic compounds using aerosol mass spectrometry: characterization, improved calibration, and implications, Atmos. Chem. Phys., 15, 253-272, doi:10.5194/acp-15-253-2015, 2015. 
Chen, Y. and Bond, T. C.: Light absorption by organic carbon from wood combustion, Atmos. Chem. Phys., 10, 1773-1787, doi:10.5194/acp-10-1773-2010, 2010.

Chung, C. E., Ramanathan, V., and Decremer, D.: Observationally constrained estimates of carbonaceous aerosol radiative forcing, Proc. Natl. Acad. Sci. USA, 109, 11624-11629, doi:10.1073/pnas.1203707109, 2012.

Clarke, A., McNaughton, C., Kapustin, V., Shinozuka, Y., Howell, S., Dibb, J., Zhou, J., Anderson, B. E., Brekhovskikh, V., Turner, H., and Pinkerton, M.: Biomass burning and pollution aerosol over North America: Organic components and their influence on spectral optical properties and humidification response, J. Geophys. Res. Atmos., 112, 1-13, doi:10.1029/2006JD007777, 2007

Corr, C. A., Hall, S. R., Ullmann, K., Anderson, B. E., Beyersdorf, A. J., Thornhill, K. L., Cubison, M. J., Jimenez, J. L., Wisthaler, A., and Dibb, J. E.: Spectral absorption of biomass burning aerosol determined from retrieved single scattering albedo during ARCTAS, Atmos. Chem. Phys., 12, 10505-10518, doi:10.5194/acp-12-10505-2012, 2012.

Dave, J. V.: Effect of Aerosols on the Estimation of Total Ozone in an Atmospheric Column from the Measurements of Its Ultraviolet Radiance, J. Atmos. Sci., 35, 899-911, doi:10.1175/15200469(1978)035<0899:EOAOTE>2.0.CO;2, 1978.

Dickerson, R. R., Kondragunta, S., Stenchikov, G., Civerolo, K. L., Doddridge, B. G., and Holben, B. N.: The impact of aerosols on solar ultraviolet radiation and photochemical smog, Science, 278, 827-830, doi:10.1126/science.278.5339.827, 1997.

Duncan, B. N., Martin, R. V., Staudt, A. C., Yevich, R. and Logan, J. A.: Interannual and seasonal variability of biomass burning emissions constrained by satellite observations, J. Geophys. Res., 108, 4100, doi:10.1029/2002JD002378, 2003.

Drury, E., Jacob, D. J., Spurr, R. J. D., Wang, J., Shinozuka, Y., Anderson, B. E., Clarke, A. D., Dibb, J., McNaughton, C., and Weber, R.: Synthesis of satellite (MODIS), aircraft (ICARTT), and surface (IMPROVE, EPA-AQS, AERONET) aerosol observations over eastern North America to improve MODIS aerosol retrievals and constrain surface aerosol concentrations and sources, J. Geophys. Res., 115, D14204, doi:10.1029/2009JD012629, 2010.

Duplissy, J., DeCarlo, P. F., Dommen, J., Alfarra, M. R., Metzger, A., Barmpadimos, I., Prevot, A. S. H., Weingartner, E., Tritscher, T., Gysel, M., Aiken, A. C., Jimenez, J. L., Canagaratna, M. R., Worsnop, D. R., Collins, D. R., Tomlinson, J., and Baltensperger, U.: Relating hygroscopicity and composition of organic aerosol particulate matter, Atmos. Chem. Phys., 11, 11551165, doi:10.5194/acp-11-1155-2011, 2011.

Fairlie, D. J., Jacob, D. J., and Park, R. J.: The impact of transpacific transport of mineral dust in the United States, Atmos. Environ., 41, 1251-1266, doi:10.1016/j.atmosenv.2006.09.048, 2007.

Feng, Y., Ramanathan, V., and Kotamarthi, V. R.: Brown carbon: a significant atmospheric absorber of solar radiation?, Atmos. Chem. Phys., 13, 8607-8621, doi:10.5194/acp-13-8607-2013, 2013.

Flores, J. M., Washenfelder, R. A., Adler, G., Lee, H. J., Segev, L., Laskin, J., Laskin, A., Nizkorodov, S. A., Brown, S. S., and Rudich, Y.: Complex refractive indices in the near-ultraviolet spectral region of biogenic secondary organic aerosol aged with ammonia., Phys. Chem. Chem. Phys., 16, 10629-10642, doi:10.1039/c4cp01009d, 2014

Forrister, H., Liu, J., Scheuer, E., Dibb, J., Ziemba, L., Thornhill, K. L., Anderson, B., Diskin, G., Perring, A. E., Schwarz, J. P., Campuzano-Jost, P., Day, D. A., Palm, B. B., Jimenez, J. L., Nenes, A., and Weber, R. J.: Evolution of brown carbon in wildfire plumes, Geophys. Res. Lett., 42, 4623-4630, doi:10.1002/2015GL063897, 2015.

Fountoukis, C. and Nenes, A.: ISORROPIA II: a computationally efficient thermodynamic equilibrium model for $\mathrm{K}^{+}$ $\mathrm{Ca}^{2+}-\mathrm{Mg}^{2+}-\mathrm{NH}_{4}^{+}-\mathrm{Na}^{+}-\mathrm{SO}_{4}^{2-}-\mathrm{NO}_{3}^{-}-\mathrm{Cl}^{-}-\mathrm{H}_{2} \mathrm{O}$ aerosols, Atmos. Chem. Phys., 7, 4639-4659, doi:10.5194/acp-7-4639-2007, 2007.

Hallquist, M., Wenger, J. C., Baltensperger, U., Rudich, Y., Simpson, D., Claeys, M., Dommen, J., Donahue, N. M., George, C., Goldstein, A. H., Hamilton, J. F., Herrmann, H., Hoffmann, T., Iinuma, Y., Jang, M., Jenkin, M. E., Jimenez, J. L., Kiendler-Scharr, A., Maenhaut, W., McFiggans, G., Mentel, Th. F., Monod, A., Prévôt, A. S. H., Seinfeld, J. H., Surratt, J. D., Szmigielski, R., and Wildt, J.: The formation, properties and impact of secondary organic aerosol: current and emerging issues, Atmos. Chem. Phys., 9, 5155-5236, doi:10.5194/acp-9-51552009, 2009.

Heald, C. L., Ridley, D. A., Kroll, J. H., Barrett, S. R. H., CadyPereira, K. E., Alvarado, M. J., and Holmes, C. D.: Contrasting the direct radiative effect and direct radiative forcing of aerosols, Atmos. Chem. Phys., 14, 5513-5527, doi:10.5194/acp-14-55132014, 2014.

Henze, D. K. and Seinfeld, J. H.: Global secondary organic aerosol from isoprene oxidation, Geophys. Res. Lett., 33, L09812, doi:doi:10.1029/2006GL025976, 2006.

Henze, D. K., Seinfeld, J. H., Ng, N. L., Kroll, J. H., Fu, T.-M., Jacob, D. J., and Heald, C. L.: Global modeling of secondary organic aerosol formation from aromatic hydrocarbons: highvs. low-yield pathways, Atmos. Chem. Phys., 8, 2405-2420, doi:10.5194/acp-8-2405-2008, 2008.

Herman, J. R., Bhartia, P. K., Torres, O., Hsu, C., Seftor, C., and Celarier, E.: Global distribution of UV-absorbing aerosols from Nimbus 7/TOMS data, J. Geophys. Res., 102, 16911, doi:10.1029/96JD03680, 1997.

Iacono, M. J., Delamere, J. S., Mlawer, E. J., Shephard, M. W., Clough, S. A., and Collins, W. D.: Radiative forcing by long-lived greenhouse gases: Calculations with the AER radiative transfer models, J. Geophys. Res., 113, D13103, doi:10.1029/2008JD009944, 2008.

IPCC: Climate Change 2014: Impacts, Adaptation, and Vulnerability. Part A: Global and Sectoral Aspects, Contribution of Working Group II to the Fifth Assessment Report of the Intergovernmental Panel on Climate Change, edited by: Field, C. B., Barros, V. R., and Dokken, D. J., Cambridge University Press, Cambridge, United Kingdom and New York, NY, USA, 2014.

Jacobson, M. Z.: Studying the effects of aerosols on vertical photolysis rate coefficient and temperature profiles over an urban airshed, J. Geophys. Res., 103, 10593, doi:10.1029/98JD00287, 1998.

Jaeglé, L., Quinn, P. K., Bates, T. S., Alexander, B., and Lin, J.-T.: Global distribution of sea salt aerosols: new constraints from in situ and remote sensing observations, Atmos. Chem. Phys., 11, 3137-3157, doi:10.5194/acp-11-3137-2011, 2011. 
Jethva, H. and Torres, O.: Satellite-based evidence of wavelengthdependent aerosol absorption in biomass burning smoke inferred from Ozone Monitoring Instrument, Atmos. Chem. Phys., 11, 10541-10551, doi:10.5194/acp-11-10541-2011, 2011.

Jo, D. S., Park, R. J., Lee, S., Kim, S.-W., and Zhang, X.: A global simulation of brown carbon: implications for photochemistry and direct radiative effect, Atmos. Chem. Phys. Discuss., 15, 2780527852, doi:10.5194/acpd-15-27805-2015, 2015.

Kirchstetter, T. W. and Thatcher, T. L.: Contribution of organic carbon to wood smoke particulate matter absorption of solar radiation, Atmos. Chem. Phys., 12, 6067-6072, doi:10.5194/acp-126067-2012, 2012.

Kirchstetter, T. W., Novakov, T., and Hobbs, P. V.: Evidence that the spectral dependence of light absorption by aerosols is affected by organic carbon, J. Geophys. Res. Atmos., 109, D21208, doi:10.1029/2004JD004999, 2004.

Koepke, P., Hess, M., Schult, I., and Shettle, E. P.: Global Aerosol Dataset, report, Max-Planck Inst. für Meteorol., Hamburg, Germany, 1997.

Kuhns, H., Knipping, E. M., and Vukovich, J. M.: Development of a United States-Mexico Emissions Inventory for the Big Bend Regional Aerosol and Visibility Observational (BRAVO) Study, J. Air Waste Manage. Assoc., 55, 677-692, doi:10.1080/10473289.2005.10464648, 2005.

Kuwata, M., Zorn, S. R., and Martin, S. T.: Using elemental ratios to predict the density of organic material composed of carbon, hydrogen, and oxygen, Environ. Sci. Technol., 46, 787-94, doi:10.1021/es202525q, 2012.

Lack, D. A. and Langridge, J. M.: On the attribution of black and brown carbon light absorption using the Ångström exponent, Atmos. Chem. Phys., 13, 10535-10543, doi:10.5194/acp13-10535-2013, 2013.

Lack, D. A., Tie, X. X., Bofinger, N. D., Wiegand, A. N. and Madronich, S.: Seasonal variability of secondary organic aerosol: A global modeling study, J. Geophys. Res., 109, D03203, doi:10.1029/2003JD003418, 2004.

Lee, C., Martin, R. V., van Donkelaar, A., O’Byrne, G., Krotkov, N., Richter, A., Huey, L. G., and Holloway, J. S.: Retrieval of vertical columns of sulfur dioxide from SCIAMACHY and OMI: Air mass factor algorithm development, validation, and error analysis, J. Geophys. Res., 114, D22303, doi:10.1029/2009JD012123, 2009.

Leibensperger, E. M., Mickley, L. J., Jacob, D. J., Chen, W.-T., Seinfeld, J. H., Nenes, A., Adams, P. J., Streets, D. G., Kumar, N., and Rind, D.: Climatic effects of 1950-2050 changes in US anthropogenic aerosols - Part 2: Climate response, Atmos. Chem. Phys., 12, 3349-3362, doi:10.5194/acp-12-3349-2012, 2012.

Liao, H., Adams, P. J., Chung, S. H., Seinfeld, J. H., Mickley, L. J., and Jacob, D. J.: Interactions between tropospheric chemistry and aerosols in a unified general circulation model, J. Geophys. Res., 108, 4001, doi:10.1029/2001JD001260, 2003.

Liao, H., Henze, D. K., Seinfeld, J. H., Wu, S., and Mickley, L. J.: Biogenic secondary organic aerosol over the United States: Comparison of climatological simulations with observations, J. Geophys. Res., 112, D06201, doi:10.1029/2006JD007813, 2007.

Lin, G., Penner, J. E., Flanner, M. G., Sillman, S., Xu, L., and Zhou, C.: Radiative forcing of organic aerosol in the atmosphere and on snow: Effects of SOA and brown carbon, J. Geophys. Res. Atmos., 119, 7453-7476, doi:10.1002/2013JD021186, 2014.
Liu, J., Bergin, M., Guo, H., King, L., Kotra, N., Edgerton, E., and Weber, R. J.: Size-resolved measurements of brown carbon in water and methanol extracts and estimates of their contribution to ambient fine-particle light absorption, Atmos. Chem. Phys., 13, 12389-12404, doi:10.5194/acp-13-12389-2013, 2013.

Liu, J., Scheuer, E., Dibb, J., Diskin, G. S., Ziemba, L. D., Thornhill, K. L., Anderson, B. E., Wisthaler, A., Mikoviny, T., Devi, J. J., Bergin, M., Perring, A. E., Markovic, M. Z., Schwarz, J. P., Campuzano-Jost, P., Day, D. A., Jimenez, J. L., and Weber, R. J.: Brown carbon aerosol in the North American continental troposphere: sources, abundance, and radiative forcing, Atmos. Chem. Phys., 15, 7841-7858, doi:10.5194/acp-15-7841-2015, 2015.

Liu, P. F., Abdelmalki, N., Hung, H.-M., Wang, Y., Brune, W. H., and Martin, S. T.: Ultraviolet and visible complex refractive indices of secondary organic material produced by photooxidation of the aromatic compounds toluene and m-xylene, Atmos. Chem. Phys., 15, 1435-1446, doi:10.5194/acp-15-1435-2015, 2015.

Mao, J., Fan, S., Jacob, D. J., and Travis, K. R.: Radical loss in the atmosphere from $\mathrm{Cu}-\mathrm{Fe}$ redox coupling in aerosols, Atmos. Chem. Phys., 13, 509-519, doi:10.5194/acp-13-509-2013, 2013.

Martin, R. V., Jacob, D. J., Yantosca, R. M., Chin, M., and Ginoux, P.: Global and regional decreases in tropospheric oxidants from photochemical effects of aerosols, J. Geophys. Res., 108, 4097, doi:10.1029/2002JD002622, 2003.

Martins, J. V., Artaxo, P., Kaufman, Y. J., Castanho, A. D., and Remer, L. A.: Spectral absorption properties of aerosol particles from 350-2500 nm, Geophys. Res. Lett., 36, 1-5, doi:10.1029/2009GL037435, 2009.

Mu, M., Randerson, J. T., van der Werf, G. R., Giglio, L., Kasibhatla, P., Morton, D., Collatz, G. J., DeFries, R. S., Hyer, E. J., Prins, E. M., Griffith, D. W. T., Wunch, D., Toon, G. C., Sherlock, V., and Wennberg, P. O.: Daily and 3-hourly variability in global fire emissions and consequences for atmospheric model predictions of carbon monoxide, J. Geophys. Res. Atmos., 116, D24303, doi:10.1029/2011JD016245, 2011.

Naik, V., Voulgarakis, A., Fiore, A. M., Horowitz, L. W., Lamarque, J.-F., Lin, M., Prather, M. J., Young, P. J., Bergmann, D., Cameron-Smith, P. J., Cionni, I., Collins, W. J., Dalsøren, S. B., Doherty, R., Eyring, V., Faluvegi, G., Folberth, G. A., Josse, B., Lee, Y. H., MacKenzie, I. A., Nagashima, T., van Noije, T. P. C., Plummer, D. A., Righi, M., Rumbold, S. T., Skeie, R., Shindell, D. T., Stevenson, D. S., Strode, S., Sudo, K., Szopa, S., and Zeng, G.: Preindustrial to present-day changes in tropospheric hydroxyl radical and methane lifetime from the Atmospheric Chemistry and Climate Model Intercomparison Project (ACCMIP), Atmos. Chem. Phys., 13, 5277-5298, doi:10.5194/acp-13-5277-2013, 2013.

Olivier, J. G. J., Van Aardenne, J. A., Dentener, F. J., Pagliari, V., Ganzeveld, L. N., and Peters, J. A. H. W.: Recent trends in global greenhouse gas emissions:regional trends 1970-2000 and spatial distributionof key sources in 2000, Environ. Sci., 2, 81-99, doi:10.1080/15693430500400345, 2005.

Park, R. J., Jacob, D. J., Chin, M., and Martin, R. V.: Sources of carbonaceous aerosols over the United States and implications for natural visibility, J. Geophys. Res., 108, 4355, doi:10.1029/2002JD003190, 2003.

Park, R. J., Jacob, D. J., Field, B. D., Yantosca, R. M., and Chin, M.: Natural and transboundary pollution influences on sulfate-nitrate-ammonium aerosols in the United 
States: Implications for policy, J. Geophys. Res., 109, D15204, doi:10.1029/2003JD004473, 2004.

Park, R. J., Kim, M. J., Jeong, J. I., Youn, D., and Kim, S.: A contribution of brown carbon aerosol to the aerosol light absorption and its radiative forcing in East Asia, Atmos. Environ., 44, 14141421, doi:10.1016/j.atmosenv.2010.01.042, 2010.

Prather, M. J., Holmes, C. D., and Hsu, J.: Reactive greenhouse gas scenarios: Systematic exploration of uncertainties and the role of atmospheric chemistry, Geophys. Res. Lett., 39, L09803, doi:10.1029/2012GL051440, 2012.

Prinn, R. G., Huang, J., Weiss, R. F., Cunnold, D. M., Fraser, P. J., Simmonds, P. G., McCulloch, A., Harth, C., Reimann, S., Salameh, P., O’Doherty, S., Wang, R. H. J., Porter, L. W., Miller, B. R., and Krummel, P. B.: Evidence for variability of atmospheric hydroxyl radicals over the past quarter century, Geophys. Res. Lett., 32, L07809, doi:10.1029/2004GL022228, 2005.

Pye, H. O. T., Liao, H., Wu, S., Mickley, L. J., Jacob, D. J., Henze, D. K., and Seinfeld, J. H.: Effect of changes in climate and emissions on future sulfate-nitrate-ammonium aerosol levels in the United States, J. Geophys. Res., 114, D01205, doi:10.1029/2008JD010701, 2009.

Ramanathan, V. and Carmichael, G.: Global and regional climate changes due to black carbon, Nat. Geosci., 1, 221-227, doi:10.1038/ngeo156, 2008.

Ridley, D. A., Heald, C. L., and Ford, B.: North African dust export and deposition: A satellite and model perspective, J. Geophys. Res., 117, D02202, doi:10.1029/2011JD016794, 2012.

Rizzo, L. V., Correia, A. L., Artaxo, P., Procópio, A. S., and Andreae, M. O.: Spectral dependence of aerosol light absorption over the Amazon Basin, Atmos. Chem. Phys., 11, 8899-8912, doi:10.5194/acp-11-8899-2011, 2011.

Russell, P. B., Bergstrom, R. W., Shinozuka, Y., Clarke, A. D., DeCarlo, P. F., Jimenez, J. L., Livingston, J. M., Redemann, J., Dubovik, O., and Strawa, A.: Absorption Angstrom Exponent in AERONET and related data as an indicator of aerosol composition, Atmos. Chem. Phys., 10, 1155-1169, doi:10.5194/acp-101155-2010, 2010.

Saleh, R., Robinson, E. S., Tkacik, D. S., Ahern, A. T., Liu, S., Aiken, A. C., Sullivan, R. C., Presto, A. A., Dubey, M. K., Yokelson, R. J., Donahue, N. M., and Robinson, A. L.: Brownness of organics in aerosols from biomass burning linked to their black carbon content, Nat. Geosci., 7, 647-650, doi:10.1038/ngeo2220, 2014.

Schnaiter, M., Schmid, O., Petzold, A., Fritzsche, L., Klein, K. F., Andreae, M. O., Helas, G., Thielmann, A., Gimmler, M., Möhler, O., Linke C., and Schurath, U.: Measurement of Wavelength-Resolved Light Absorption by Aerosols Utilizing a UV-VIS Extinction Cell, Aerosol Sci. Technol., 39, 249-260, doi:10.1080/027868290925958, 2005.

Spivakovsky, C. M., Logan, J. A., Montzka, S. A., Balkanski, Y. J., Foreman-Fowler, M., Jones, D. B. A., Horowitz, L. W., Fusco, A. C., Brenninkmeijer, C. A. M., Prather, M. J., Wofsy, S. C., and McElroy, M. B.: Three-dimensional climatological distribution of tropospheric OH: Update and evaluation, J. Geophys. Res., 105, 8931, doi:10.1029/1999JD901006, 2000.

Spurr, R. J. D.: VLIDORT: A linearized pseudo-spherical vector discrete ordinate radiative transfer code for forward model and retrieval studies in multilayer multiple scattering me- dia, J. Quant. Spectrosc. Radiat. Transf., 102, 316-342, doi:10.1016/j.jqsrt.2006.05.005, 2006.

Stier, P., Seinfeld, J. H., Kinne, S., and Boucher, O.: Aerosol absorption and radiative forcing, Atmos. Chem. Phys., 7, 5237-5261, doi:10.5194/acp-7-5237-2007, 2007.

Sun, H., Biedermann, L., and Bond, T. C.: Color of brown carbon: A model for ultraviolet and visible light absorption by organic carbon aerosol, Geophys. Res. Lett., 34, L17813, doi:10.1029/2007GL029797, 2007.

Torres, O., Bhartia, P. K., Herman, J. R., Ahmad, Z., and Gleason, J.: Derivation of aerosol properties from satellite measurements of backscattered ultraviolet radiation: Theoretical basis, J. Geophys. Res., 103, 17099, doi:10.1029/98JD00900, 1998.

Torres, O., Bhartia, P. K., Sinyuk, A., Welton, E. J., and Holben, B.: Total Ozone Mapping Spectrometer measurements of aerosol absorption from space: Comparison to SAFARI 2000 ground-based observations, J. Geophys. Res., 110, D10S18, doi:10.1029/2004JD004611, 2005.

Torres, O., Tanskanen, A., Veihelmann, B., Ahn, C., Braak, R., Bhartia, P. K., Veefkind, P., and Levelt, P.: Aerosols and surface UV products from Ozone Monitoring Instrument observations: An overview, J. Geophys. Res., 112, D24S47, doi:10.1029/2007JD008809, 2007.

Torres, O., Ahn, C., and Chen, Z.: Improvements to the OMI nearUV aerosol algorithm using A-train CALIOP and AIRS observations, Atmos. Meas. Tech., 6, 3257-3270, doi:10.5194/amt-63257-2013, 2013.

Tsigaridis, K. and Kanakidou, M.: Global modelling of secondary organic aerosol in the troposphere: a sensitivity analysis, Atmos. Chem. Phys., 3, 1849-1869, doi:10.5194/acp-3-1849-2003, 2003.

Turpin, B. J. and Lim, H.-J.: Species Contributions to $\mathrm{PM}_{2.5}$ Mass Concentrations: Revisiting Common Assumptions for Estimating Organic Mass, Aerosol Sci. Technol., 35, 602-610, doi:10.1080/02786820119445, 2001.

van Donkelaar, A., Martin, R. V., Leaitch, W. R., Macdonald, A. M., Walker, T. W., Streets, D. G., Zhang, Q., Dunlea, E. J., Jimenez, J. L., Dibb, J. E., Huey, L. G., Weber, R., and Andreae, M. O.: Analysis of aircraft and satellite measurements from the Intercontinental Chemical Transport Experiment (INTEX-B) to quantify long-range transport of East Asian sulfur to Canada, Atmos. Chem. Phys., 8, 2999-3014, doi:10.5194/acp-8-2999-2008, 2008.

Wang, X., Heald, C. L., Ridley, D. A., Schwarz, J. P., Spackman, J. R., Perring, A. E., Coe, H., Liu, D., and Clarke, A. D.: Exploiting simultaneous observational constraints on mass and absorption to estimate the global direct radiative forcing of black carbon and brown carbon, Atmos. Chem. Phys., 14, 10989-11010, doi:10.5194/acp-14-10989-2014, 2014.

Yang, M., Howell, S. G., Zhuang, J., and Huebert, B. J.: Attribution of aerosol light absorption to black carbon, brown carbon, and dust in China - interpretations of atmospheric measurements during EAST-AIRE, Atmos. Chem. Phys., 9, 2035-2050, doi:10.5194/acp-9-2035-2009, 2009.

Yevich, R. and Logan, J. A.: An assessment of biofuel use and burning of agricultural waste in the developing world, Global Biogeochem. Cy., 17, 1095, doi:10.1029/2002GB001952, 2003.

Zhang, L., Jacob, D. J., Kopacz, M., Henze, D. K., Singh, K. and Jaffe, D. A.: Intercontinental source attribution of ozone pollu- 
tion at western U.S. sites using an adjoint method, Geophys. Res. Lett., 36, L11810, doi:10.1029/2009GL037950, 2009.

Zhang, X., Lin, Y.-H., Surratt, J. D., and Weber, R. J.: Sources, composition and absorption Ångström exponent of lightabsorbing organic components in aerosol extracts from the Los Angeles Basin, Environ. Sci. Technol., 47, 3685-3693, doi:10.1021/es305047b, 2013.
Zhong, M. and Jang, M.: Dynamic light absorption of biomassburning organic carbon photochemically aged under natural sunlight, Atmos. Chem. Phys., 14, 1517-1525, doi:10.5194/acp-141517-2014, 2014. 